\title{
The Double-Edged Sword Role of Viruses in Gastric Cancer
}

\author{
Paulina Niedźwiedzka-Rystwej ${ }^{1, *,+(\mathbb{C})}$, Ewelina Grywalska ${ }^{2,+}{ }^{\circledR}$, Rafał Hrynkiewicz $^{1}{ }^{1}$, \\ Mikołaj Wołącewicz ${ }^{1}$, Rafał Becht ${ }^{3}(\mathbb{D})$ and Jacek Roliński ${ }^{2}$ \\ 1 Institute of Biology, University of Szczecin, Felczaka 3c, 71-412 Szczecin, Poland; \\ rafal.hrynkiewicz@gmail.com (R.H.); mikolaj.wolacewicz@gmail.com (M.W.) \\ 2 Department of Clinical Immunology and Immunotherapy, Medical University of Lublin, \\ 20-093 Lublin, Poland; ewelina.grywalska@gmail.com (E.G.); jacek_rolinski@wp.pl (J.R.) \\ 3 Clinical Department of Oncology, Chemotherapy and Cancer Immunotherapy, Pomeranian Medical \\ University of Szczecin, 70-204 Szczecin, Poland; rbecht@pum.edu.pl \\ * Correspondence: paulina.niedzwiedzka-rystwej@usz.edu.pl \\ + These authors contributed equally.
}

Received: 30 May 2020; Accepted: 23 June 2020; Published: 24 June 2020

\begin{abstract}
Due to its high morbidity and mortality, gastric cancer is a topic of a great concern throughout the world. Major ways of treatment are gastrectomy and chemotherapy, unfortunately they are not always successful. In a search for more efficient therapy strategies, viruses and their potential seem to be an important issue. On one hand, several oncogenic viruses have been noticed in the case of gastric cancer, making the positive treatment even more advantageous, but on the other, viruses exist with a potential therapeutic role in this malignancy.
\end{abstract}

Keywords: gastric cancer; oncogenic viruses; oncolytic viruses; immunology; cancer treatment

\section{Introduction}

Gastric cancer is, according to different sources, the 5th most common cancer in the world [1]. According to the GLOBOCAN 2018 database, over 1 million cases were reported in 2018, including 781,631 deaths [1]. However, using this database, one can notice a downward trend in the incidence of this particular type of cancer [2]. Tumors are caused not only by accidental errors in the process of DNA replication and repair, but also by the body's exposure to harmful physical and chemical factors. Diet and activity have a significant impact on morbidity. All these factors affect a number of cytogenetic changes leading to uncontrolled cell proliferation and, as a result, the formation of tumors [1]. Viruses are known to possess oncogenic function, meaning that they are suspected of causing cancer in about every 10th case [3]. The most prominent and frequent pathogens related to cancers are human papillomavirus (HPV; associated with 640,000 cases), hepatitis B virus (HBV; 420,000 cases), hepatitis C virus (HCV; 170,000 cases) and Epstein-Barr virus (EBV; 120,000 cases) [3], but the oncogenic role of several others have also been confirmed in different types of cancer (Table 1).

Nevertheless, viruses have two faces-apart from being a cancer factor, viruses can also kill malignant cells, simultaneously sparring the healthy ones [4]. This oncolytic feature is interesting, as it potentially may be translated into clinical/therapeutic advantage, showing, that viruses have a double-sword role in gastric cancer. 
Table 1. Human oncogenic virus.

\begin{tabular}{|c|c|c|c|}
\hline Family & Virus & Cancer Type & References \\
\hline \multicolumn{4}{|c|}{ 1. DNA viruses } \\
\hline Hepadnaviridae & HBV & $\begin{array}{l}\text { Hepatocellular carcinoma, cholangiocarcinoma *, } \\
\text { non-Hodgkin lymphoma *, gastric cancer * }\end{array}$ & {$[5-12]$} \\
\hline \multirow[t]{2}{*}{ Herpesviridae } & EBV/HHV-4 & $\begin{array}{l}\text { Nasopharyngeal carcinoma, Burkitt lymphoma, } \\
\text { immune-suppression-related non-Hodgkin } \\
\text { lymphoma, extranodal natural killer/T-cell } \\
\text { lymphoma (nasal type), posttransplant } \\
\text { lymphoproliferative disorder, Hodgkin lymphoma, } \\
\text { breast cancer *, gastric cancer *, leiomyosarcomas *, } \\
\text { AIDS-associated lymphomas * }\end{array}$ & {$[5-15]$} \\
\hline & KSHV/HHV-8 & $\begin{array}{l}\text { Kaposi sarcoma, primary effusion lymphoma, } \\
\text { AIDS-related lymphoproliferative disorder *, } \\
\text { multicentric Castleman's Disease * }\end{array}$ & {$[5-12]$} \\
\hline Papillomaviridae & HPV & $\begin{array}{l}\text { Cervical cancer, oropharyngeal cancers, anal cancer, } \\
\text { penile cancer, vaginal cancer, vulvar cancer, larynx } \\
\text { cancer * }\end{array}$ & {$[5,6,8-13,16,17]$} \\
\hline \multicolumn{4}{|c|}{ 2. RNA viruses } \\
\hline Flaviviridae & $\mathrm{HCV}$ & $\begin{array}{l}\text { Hepatocellular carcinoma, } \\
\text { non-Hodgkin's lymphoma, } \\
\text { cholangiocarcinoma *, }\end{array}$ & {$[5-12]$} \\
\hline Retroviridae & HTLV-1 & Adult T-cell leukemia/lymphoma (ALT) & [5-12] \\
\hline
\end{tabular}

\section{Oncogenic Viruses}

Several viruses are known to have a confirmed oncogenic role in different types of malignancies (Table 1). Nevertheless, there are also viruses, with only a potential oncogenic role, where studies are limited or ambiguous (Table 2).

Table 2. Potentially oncogenic human viruses.

\begin{tabular}{|c|c|c|c|}
\hline Family & Virus & Cancer Type & References \\
\hline \multicolumn{4}{|c|}{ 1. DNA viruses } \\
\hline Adenoviridae & $\begin{array}{c}\text { HAdV-A 12, 18, } 31 \\
\text { HAdV-D } 9\end{array}$ & Various solid tumors in rodents & {$[5,9]$} \\
\hline \multirow{2}{*}{ Papovaviridae } & $\mathrm{MCV} / \mathrm{MCPyV}$ & Merkel cell carcinoma & {$[5-7,11,16]$} \\
\hline & $\mathrm{JCV}, \mathrm{BKV}$ & Solid tumors in rodents and primates & {$[5,9,11]$} \\
\hline \multicolumn{4}{|c|}{ 2. RNA viruses } \\
\hline \multirow{4}{*}{ Retroviridae } & HIV-1 & $\begin{array}{l}\text { Kaposi's sarcoma, non-Hodgkin lymphoma, } \\
\text { Hodgkin's lymphoma, cervical cancer, anal cancer, } \\
\text { conjunctival cancer, vulvar cancer *, vaginal cancer } \\
\text { *, penile cancer *, non melanoma skin cancer *, } \\
\text { hepatocellular carcinoma }\end{array}$ & {$[5,11]$} \\
\hline & HIV-2 & Kaposi's sarcoma *, non-Hodgkin's lymphoma * & [11] \\
\hline & HERV-K & Breast cancer & [11] \\
\hline & XMRV & Prostate cancer & [11] \\
\hline
\end{tabular}

HAdV-A: Human Adenovirus A; HAdV-D: Human Adenovirus D; MCV/MCPyV: Merkel cell polyomavirus; JCV: JC polyomavirus; BKV: BK polyomavirus; HIV-1: Human immunodeficiency virus 1; HIV-2: Human immunodeficiency virus 2; HERV-K: Human endogenous retrovirus K; XMRV: Xenotropic murine leukemia virus-related virus. * Cancer sites with limited evidence. 
Oncogenic Viruses and the Immune System

The invasion of virus into the host caused a cascade of immune system actions [18]. It is worth remembering, that oncogenic viruses generally maintain chronic infections, not acute states, while the first resembling the state of carcinogenesis [19]. There are two ways of targeting the host cell ensuring cellular replication-virus may be either maintained as genetic element and viral genomes form episomes or it can integrate into the host genomic DNA [19]. In both mechanisms, a specific interaction is seen between the virus and the host cell, while oncogenic virus nurture infection of a controlled number of cells [19]. If the cancer cell dies, it will be also the end of the virus, so in a way the replication of the virus keeps both sides of the contract running. Over all, carcinogenesis is increasing, when antiviral immune responses are impaired [20]. Oncogenic viruses are also manipulating several signaling pathways, what severely interferes the actions. Main pathways are Pi-3K-AKT-mTor, MAPK, Notch, WNT- $\beta$-catenin and NK- $\kappa B$ [21].

Direct tumorigenesis is mediated by carcinogenic agents helping to keep the tumor phenotype and help the virus maintain as a genetic element (commonly retroviruses), while indirect transformation is conditions by two mechanisms-one is triggering chronic infection, and the second is immunosuppression (mostly presented by HBV, HVC and HIV). It is worth mentioning, that EBV, but under the same conditions also $\mathrm{HBV}$ and $\mathrm{HCV}$, are viruses using both direct and indirect mechanism of carcinogenesis [19].

Summing up, several mechanisms are enumerated as viral oncogenic mechanisms (Figure 1), and all those mechanisms are directly or indirectly connected to different stages of the viral life cycle [19], like genomic instability, the cell proliferation, resistance to apoptosis, alterations in DNA repair mechanisms and cell polarity changes $[10,19]$. Viral agents also indirectly contribute to the development of cancer mainly through immunosuppression or chronic inflammation, but also through chronic antigenic stimulation. There is also evidence that viruses can modulate the malignant properties of an established tumor [19]. Moreover, one of the strategies to avoid antiviral immunity by oncogenic viruses (DNA and RNA) is the ability to regulate host DNA methylation [20]. Inducing hypermethylation of immune genes is leading to viral replication and persistence and is a common mechanism to potentiate virus-induced cancer progression [20]. An important factor impacting oncogenesis may also by miRNA, participating in cell transformation, by inhibiting mRNA translation [19,22].

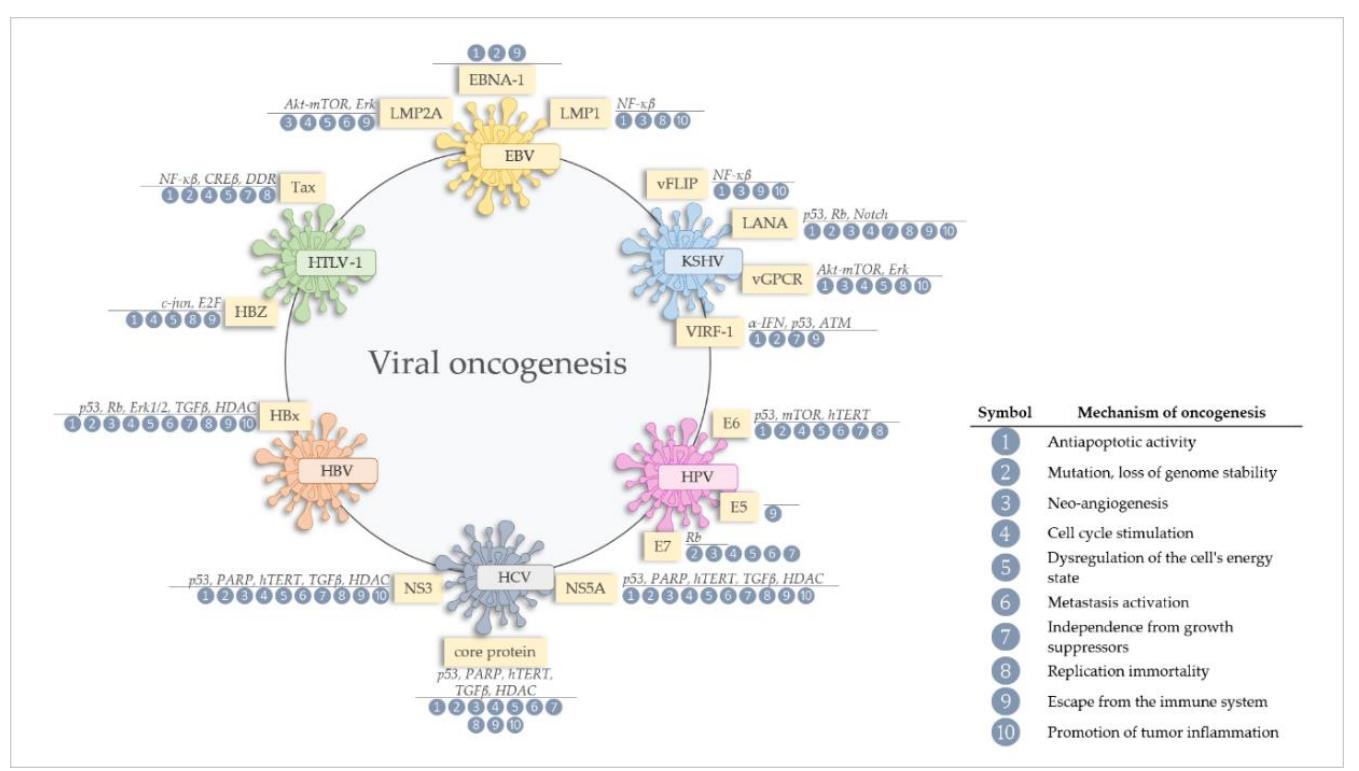

Figure 1. Mechanisms of oncogenesis and the involvement of viral oncoproteins in gastric cancer. All virus-associated tumors result from the cooperation of many oncogenic mechanisms. In gastric cancer, viral oncoproteins are triggering all (1-10) of the described oncogenic scenarios. 


\section{Oncogenic Viruses in Gastric Cancer}

\subsection{Epstein-Barr Virus}

The Epstein-Barr virus is one of the human herpesviruses with a proved oncogenic potential [1]. It belongs to the Herpesviridae family in the Herpesvirales order [23]. It has linear double-stranded DNA 168-184 kbp long, which consists of 85 genes [24]. Due to the difference in the EBNA gene, 2 subtypes of EBV 1 and 2 were distinguished [1,24,25].

EBV, like all herpesviruses, has a latent and lytic phase [26]. The infection of B lymphocytes with EBV in cell culture results in the establishment of an immortalized B cell line [27]. There are several proteins encoded in the EBV genome that have transformational potential. One of them is LMP1 (latent membrane protein), which has the ability to transform equal types of cells, including fibroblasts in rodents [28]. In addition, the LMP1 gene is necessary for the virus to kill B lymphocytes, since its removal causes a lack of transformation [28].

LMP1 has many transmembrane spanning domains and its carboxyl terminus may interact with several tumor necrosis factor receptor associated factors (TRAF) [26,29]. The interaction between LMP1 and TRAF results in high expression of the nuclear factor kB (NF-kB) in LMP1-expressing epithelial and B cells [26]. LMP1 also upregulates the expression of some genes responsible for apoptosis and adhesion, including A20, bcl2 and ICAM-1 [26]. In addition, it activates the expression of interferon regulatory factor 7 (IRF-7) [30], matrix metalloproteinase 9 (MMP-9) and fibroblast growth factor-2 (FGF-2) [31].

Another viral gene, LMP2, has been shown to inhibit B-cell receptor (BCR) signaling [32]. It works by sequestering the Src family members Fyn and Lyn, preventing their translocation into lipid rafts with BCR, thereby inhibiting BCR activity [33].

Other viral genes that encode transforming potential include EBV nuclear antigen 2 and 3 (EBNA2 and EBNA3). EBNA2, like LMP1, is necessary for the transformation of B cells, because the removal of this gene from the wild type EBV makes the virus unable to kill B cells [26,34]. Among the genes encoding EBNA3, EBNA3A and EBNA3C, they are necessary for the transformation of B cells, while EBNA3B is unnecessary [35]. All three EBNA3 proteins can interfere with EBNA2 activation, interfering with its intercalation with RBP-Jk DNA-binding protein, thereby suppressing its EBNA2-mediated transactivation [26]. EBNA3C may therefore promote cell proliferation and cross the G1-S phase checkpoint and may also work with EBNA2 and EBNA3A to modulate cell gene expression in EBV infected lymphocytes.

In general, the oncogenic mechanism of EBV relies on coding LMP1 and LMP2, EBNA1-3, leader protein (LP), BamHI A reading frame 1 (BARF1) and BamHI A rightward transcript miRNAs, which their role is to promote transformation of B cells and epithelial cells and block pro-apoptotic proteins in host cells [20]. Lately it was also confirmed [20] that stimulation of DNA hypermethylation of host genes might contribute to carcinogenesis.

It is widely believed that EBV contributes to the development of many diseases, including Burkitt's lymphoma, Hodgkin's lymphoma, diffuse large B-cell lymphoma, lymphoproliferative disorder in people with immunodeficiency [24,36,37], post-transplant lymphoproliferative disease, central nervous system lymphoma, non-Hodgkin lymphoma, oral hairy leukoplakia [38] and gastric cancer [24,38-44].

Many different independent studies confirm the presence of EBV virus in cancer cells, among others, in lymphoepigastric adenocarcinomas [40], lymphoepithelioma-like gastric carcinoma with marked lymphocytic stroma [41]. In general, EBV is detected in approximately $10 \%$ of gastric cancer cases [42,45]. Its existence in gastric cancer was first discovered in 1990, by the means of a polymerase chain reaction (PCR) [46]. The EBV-encoded small RNA 1 (EBER1) gene is used to confirm the presence of the virus in cancer cells. It is a viral protein attributed to the function of combining viral DNA with host chromosomes, which enables its replication by host DNA polymerase [24]. The presence of this gene can be confirmed by carrying out both the polymerase reaction and in situ hybridization 
(ISH) [44]. When the ISH method is used, EBER1 signals are detected in the nuclei of gastric cancer cells $[41,42,47]$. In EBV positive stomach cancer (EBVaGC), all cancer cells carry the EBER1 gene [43].

Published in 2014, the Cancer Genome Atlas (TCAG) study, presented the gastric adenocarcinomas division into four groups: 1 . EBVaGC; 2 . microsatellite instability (MSI); 3. chromosomal instability (CIN) and 4. genomically stable (GS) tumors [48]. It has been reported that EBV 16 positive tumors are characterized by the transmission of recurrent mutations in the PIK3CA gene, DNA hypermethylation and overexpression of the JAK2, PD-L1 and PD-L2 genes [38,43,48,49].

In 2015, Chen et al. [44] published a systematic review in which they focused not only on studies showing the presence of the EBER1 gene in cancer cells and also in non-tumor tissues adjacent to the stomach in cancer patients, in the non-tumor mucosa of healthy patients, patients with mild stomach diseases and in the deceased individuals and studies comparing anti-EBV antibodies in the serum of healthy and sick patients. They analyzed 47 studies; in total 9909 patients were examined, including 8069 patients and 1840 healthy people. The EBER1 positivity tested by the ISH method was significantly higher and ranged from $5 \%$ to $17.9 \%$ in the tumor tissue than in the adjacent mucosa in the same patients or biopsies from all control groups-almost $0 \%$. They also noted that some cases of confirmation of the presence of EBER1 by PCR were not confirmed by ISH. They concluded that the ISH method makes it possible to effectively determine the relationship between gastric cancer and EBV infection, and the PCR method is not efficient enough.

\section{2. $H H V-8$}

Human herpesvirus 8, like EBV, belongs to the Herpesvirales family, to the subfamily Gammaherpesvirinae [23]. It was first discovered in AIDS-related Kaposi's sarcoma in 1994, which owes its second name: Kaposi sarcoma herpes virus (KSHV) [50]. KSHV is also involved in the development of primary effusion lymphoma, multicentric Castleman's disease (MCD) [24,51,52] and B-cell lymphoproliferative disorders that can be converted to KSHV-associated non-Hodgkin's lymphoma and also primary effusion lymphoma (PEL) $[39,53]$.

The KSHV genome contains a variety of genes responsible for transformation, signaling, prevention of apoptosis and avoidance of immunity. Researchers believe that HHV-8 transforms cells through a paracrine mechanism because several studies have shown high levels of cytokines and growth factors in KS and MCD changes [26].

KSHV can immortalize primary bone marrow endothelial cells and induce cell proliferation, anchoring independence and survival of these cells. Researchers also found that only a subset of transformed endothelial cells contained viral DNA, which firmly said that adjacent uninfected cells survived due to a mechanism involving cytokines secreted by infected cells [54]. On this basis, it has been suggested that transformation of KSHV is dependent on paracrine factors [26].

The KSHV K1 genes and viral G-protein-coupled receptors (vGPCR) have oncogenic potential. The K1 protein is able to transform rodent fibroblasts in vitro, and when injected into nude mice, these cells induce numerous and widespread tumors. In addition, $\mathrm{K} 1$ has the ability to functionally replace the saimiri transforming protein (STP) of herpesvirus saimiri (HVS) in vitro and in vivo to induce lymphoma in marmoset monkeys [26]. Transgenic animals expressing K1 develop sarcomas and lymphomas [55]. In addition, $\mathrm{K} 1$ can induce B cell signaling and proliferation through an immunoreceptor tyrosine-based activation motif (ITAM) and blocking Fas-induced apoptosis of these cells $[56,57]$. In addition, Wang et al. found that K1 can activate the NF-kB and PI3K paths. In the endothelial cells, researchers showed that $\mathrm{K} 1$ upregulates the expression and secretion of vascular endothelial growth factor (VEGF) and MMP-9 [58,59].

Similarly to the K1 protein, the KSHV vGPCR protein works, which has the ability to transform NIH 3 T3 cells in vitro. vGPCR can also activate phospholipase C (PLC) and PI3K pathways [60]. This protein also immortalizes primary endothelial cells and transgenic mice expressing vGPCR develop angioproliferative changes similar to Kapossi sarcoma-like lesions [61]. In addition, expression of vGPCR in various cell types leads to upregulation of many cytokines and paracrine factors. Thus, this 
specific viral protein may be involved in the development of KSHV-related cancer by inducing and supporting cell proliferation.

In addition to the two proteins mentioned above, the KSHV genome also encodes: interferon 1 regulatory factor (vIRF-1) and the Kaposin/K12 gene. Both of these proteins have in vitro transformation potential [26]. In addition, researchers have shown that LANA (latency-associated nuclear antigen) immortalizes endothelial cells and induces B cell and lymphoma hyperplasia in mice [62,63].

Despite learning about many models of KSHV transformation and oncogenesis, the origin of KS-related tumor cells remains controversial [64]. In order to understand the exact mechanism of KSHV oncogenesis, further research is needed, both in human and animal models, because more transformation pathways than presented may exist.

KSHV cannot transform any cells in culture and does not sustain its own persistence without EBV co-infection [39,65]. In the case of the PEL, the researchers found that KSHV/EBV co-infection occurred in most of the cases [66]. The role of EBV in this disease is not fully understood. It is believed that in this very case EBNA1 gene expression increases KSHV virus load and an increase in the extent of LANA [66]. It is possible that the function of the EBV in KSHV/EBV co-infection in other cases is also to enhance the virulence and the KSHV genome expression in the host cells.

This virus has a long dsDNA chain (over $140 \mathrm{kbp}$ ) [24]. Unlike EBV, KSHV does not connect to chromosomes, but connects to genomic DNA indirectly, due to the LANA1 protein with histones H2A and H2B [67].

\subsection{Human Papillomavirus}

Human papillomavirus (HPV) belongs to the Papillomaviridae family [23]. Among the many distinguished types of HPV, type 16, 18, 33, 45, 52 and 58 are associated with various types of cancer, including cervical, anogenital, penile and nasopharyngeal cancers [24,68-70]. Research on the potential role and development of HPV-16 and HPV-18 viruses in cervical cancer was initiated by zur Hausen et al. in the 1970s [71-73], for which he was awarded the Nobel Prize in Medicine and Physiology in 2008 [74]. This shows how important it is to study the role of oncoviruses, not only $\mathrm{HPV}$, in order to fully understand their mechanisms of action, develop methods for their detection and discover effective treatment methods.

The HPV genome is built of 7-8 kbp circular double-stranded DNA [75]. After many studies, it has finally been determined that the most common route of transmission of this virus is the sexual route [76]. However, HPV is a very stable virus and can survive on surfaces for up to several days. The virus is also resistant to some disinfectants [76-78]. For this reason, the virus can also be transmitted through by non-sexual means: either by way of mother to child, fomites, self-inoculation or nosocomial infection [76]. It is very possible that all the HPV transmission routes have not yet been discovered. For this purpose, long-term prospective studies should be undertaken. Although the sexual route is the most common way it is very necessary to spread among the public about alternate modes of transmission [79].

Primary HPV infection occurs in basal epithelial stem cells [26]. Then the virus traverses upwards and replicates in finally differentiated keratinocytes, and is shed from the stratum corneum $[26,80]$. The HPV genome lacks an enzyme necessary for replication-DNA polymerase-and therefore the replication of the viral genome depends on the stimulation of cellular DNA synthesis in infected cells [26].

In the vast majority of cervical cancers, HPV integrates with the host genome, resulting in loss of expression of the E2 viral gene, which is the transcriptional repressor of the E6 and E7 genes. As a result, there is an increased expression of oncoproteins encoded by these two genes [80]. E6 and E7 proteins from high-risk virus strains have strong transformational abilities. It has been shown $[26,81,82]$ that these proteins immortalize cells in vitro and induce skin tumors in transgenic animals. 
HPV viral oncoproteins attack tumor suppressors. The overall result is cell cycle and cell growth dysregulation and the inhibition of the apoptosis. E6 binds the p53 transcription factor and induces its degradation [83]. E6 binds to ubiquitin ligase forming the E6-AP complex, binding p53 and causing ubiquitination and proteosomal destruction of proteins [84]. In addition, E6 may induce telomerase activity and lead to cell immortalization [85].

E7 binds members of the retinoblastoma $(\mathrm{Rb})$ family [86]. This protein hinders $\mathrm{Rb}$ function and allows cells to enter the $S$ phase of the cell cycle. E7 binds to the hypophosphorylated form of Rb and prevents its binding to E2F transcription factor. Free E2F transcription factors promote the expression of genes required for cell DNA synthesis, thereby pushing the cell into the cell cycle [26,87]. In addition, E7 stimulates cyclin-A and cyclin-E dependent kinase activity and deactivates p21/WAF1 and p27/KIP1 kinase inhibitors. E7 may also be the cause of the synthesis of abnormal centrioles and aneuploidy at an early stage of the oncogenic process [26].

Treatment of the effects of his infection is possible due to the discovery of HPV vaccines. Available vaccines protect against two, four or nine types of HPV, but each of them is directed at least to HPV-16 and HPV-18 - the types of virus whose infection causes the greatest risk of developing cervical cancer [88].

In 2018, de Souza et al. conducted studies aimed at demonstrating correlations in co-infection with HPV, EBV and Helicobacter (H.) pylori in gastric cancer [13]. Three hundred and two samples were tested, most of which (55\%) were classified as an enteric subtype. All three pathogens were found in the samples tested, including H. pylori in $87 \%$, EBV in $20 \%$ and HPV in $3 \%$. Interestingly, among HPV-positive samples, researchers found only viruses of Types 16 and 18. Based on the research, they concluded that human papillomavirus is not involved in the development of gastric cancer [13].

No other studies were found that clearly and undeniable confirm the correlation between HPV infection and gastric cancer.

\subsection{Hepatitis B Virus}

The hepatitis B virus (HBV) is a human, partially double-stranded DNA virus with a diameter of $42-47 \mathrm{~nm}$ and a genome of about $3.2 \mathrm{kbp}[19,89]$. It belongs to the family of Hepadnaviridae of the genus Orthohepadnavirus [23]. It is replicated in hepatocytes via indirect RNA using viral reverse transcriptase [90]. The virus has a natural tropism to the liver and in most cases, the infection leads to liver damage, with the consequence that hepatocellular carcinoma develops [91,92].

The HBV genome has a small HBx region that plays an important role in oncogenesis [93]. The HBx is a relatively small $17 \mathrm{kDa}$ polypeptide [94,95]. The HBx activates many different promoter elements. It is responsible for activating transcription of viral and cellular genes. It changes signal transduction, disrupting the signaling cascade above the transcription complex. These signaling cascades trigger the activation of many factors such as AP-1, NF-kB, SP1 and Oct-1 [96]. The HBx protein stimulates entry into the cell cycle by activating selected cyclins and cyclin-dependent kinase pathways, as well as pathways such as Wnt, ras, PI3K, JAK/STAT, NF-kB and Hedgehog, which promote survival and growth $[97,98]$. Nuclear HBx affects transcription regulation by activating CREB, ATF-2, ATF-3, NFAT, $\mathrm{C} / \mathrm{EBP} \beta$ and SMAD4 complexes and facilitates the introduction of epigenetic changes that affect the expression of the host cell gene $[99,100]$. Changes in HBx-mediated miRNA levels both modulate the expression of oncogene and the suppressor gene [101]. Hepatitis B virus avoids both growth suppression and immune destruction by blocking the process of apoptosis. Internal apoptosis is caused by the occurrence of oxidative stress caused by the virus itself, while external apoptosis is activated through the immune system [98]. The HBx blocks the activation of the key mediator of congenital antiviral signaling, which is the MAVS (mitochondrial antiviral signaling protein), while the prevention of external apoptosis is caused by TNF $\alpha, \operatorname{TGF} \beta$ and Fas by blocking caspases 8 and 3 and activating NF-kB, the latter being responsible for liver protection [98]. The HBx protein replaces the negative regulation of TGF $\beta$ growth and converts it into a tumor promoter [100]. Mitochondrial-associated HBx causes an increase in reactive oxygen species (ROS). High levels of ROS, combined with the 
progression of the cell cycle, increase the risk of occurrence and spread of mutations many times over [100]. The HBx promotes cell division by directly interacting with the $\mathrm{p} 53$ protein by suppressing binding and transcriptional down regulation, in addition it promotes $\mathrm{Rb}$ inactivation and down regulates some cdk inhibitors [96,98]. HBx also inhibits DNA 1 binding protein (DDB1) damage during repair of nucleotide excision, and also promotes the appearance of multinucleated cells, chromosome rearrangement and micronucleus formation [100]. In cell culture experiments, indeed, HBx expression significantly inhibited the ability of cells to repair damaged DNA [102]. The HBx can also cause increased angiogenesis and metastasis, through the transcription factor HIF1 $\alpha$, which activates Ang-2 (angiopoietin-2) and VEGF (vascular endothelial growth factor) [100]. The HBx protein influences the development of all key features of cancer and does not have to interact with other viral oncogenes [96].

Chronic HBV infection is associated with EHC (extra-hepatic cancers) such as pancreatic cancer, non-Hodgkin's lymphoma and gastric cancer. Hepatitis B virus, through the bloodstream, can lead to infection of tissues of organs other than the liver. HBV antigens outside the liver are also often detected in the stomach, gastrointestinal tract, pancreas and kidney $[92,103,104]$. It is possible that HBV can replicate in extra-hepatic tissues and plays an oncogenic role [92]. Over the past several years, there have been many independent studies showing the relationship between HBV surface antigen (HBsAg) and gastric cancer $[91,92,103-107]$.

Chen et al. [106] in 2004 noticed that very often a co-infection of the hepatitis B virus and Helicobacter (H.) pylori was observed in patients. The study involved 72 patients of Jiangsu Province in China, including 28 patients with diagnosed chronic hepatitis B and 44 patients with advanced hepatic cirrhosis caused by hepatitis B who were the study group. Thirty patients with gastritis but no liver disease was included in the control group [106]. There was no significant difference between the cirrhosis group and the group with chronic hepatitis. It was observed that HBV antigen expression in the gastric mucosa with positive $H$. pylori infection was $69.8 \%$ and with negative $73.7 \%(p>0.005)$ [106]. It has been concluded that $\mathrm{HBsAg}$ and $\mathrm{HBcAg}$ overexpression coexist with $\mathrm{H}$. pylori antigen expression in the gastric mucosa of persons with $H$. pylori infection, thus early treatment of $H$. pylori infection may be beneficial for the prognosis of patients with chronic liver disease [106]. In 2011, research was carried out in China in which ten commonly occurring extrahepatic tumors were assessed. The tests evaluated the presence of $\mathrm{HBsAg}$ in cancerous tissues. Approximately $14 \%$ of patients with confirmed gastric cancer received a positive result for the presence of the hepatitis B surface antigen (HBsAg) [92,107]. In contrast, in the Republic of Korea, the presence of HBsAg was confirmed in $3.4 \%$ of women and $4.7 \%$ of men with stomach cancer [92,103].

Ghasemi et al. [104] in 2012 presented their research, in which they examined the effect of HBV on gastric cancer in the population of Northern Iran. Researchers collected 100 biopsy blocks with paraffin fixed in formalin and gastric cancer was confirmed in all trials [104]. In the study group, 69\% of patients with gastric cancer were middle-aged men and $31 \%$ were women. The authors did not show the presence of the HBV genome in gastric cancer in their studies, which indicates that HBV is not correlated with the development of gastric cancer in the inhabitants of Northern Iran [104].

The first studies that showed the actual relationship between hepatitis B virus infection and gastric cancer appeared in 2015. Wei et al. [105] conducted a retrospective follow-up study with 580 cases and 580 controls that matched each other by age, gender and year of diagnosis. The relationship between gastric cancer and HBV infection was investigated using one- and multi-dimensional unconditional logistic regression analysis. The results obtained show that the HBsAg antigen is positively associated with gastric cancer (AOR (95\% CI): 1.49 (1.06-2.10)) [105]. However, the relationship remained significant in patients with no family history of cancer (AOR (95\% CI): (1.06-2.11)). In the group with negative $\mathrm{HBsAg}$, which are anti-HBc positive/anti-HBs negative, which probably suggested latent HBV infection, also shows some association with gastric cancer. Besides, some synergistic effects have been demonstrated between HBV infection and blood group A in gastric cancer. Studies directly show that HBV infection is positively associated with the development of gastric cancer, especially in a 
group of patients who have no confirmed family history of gastric cancer. Wei et al. stated that further prospective studies are needed to finally confirm the association of HBV with gastric cancer [105].

In 2019, the latest research appeared that aimed to confirm the relationship between HBV infection and gastric cancer [92]. The correlation between gastric pathology and hepatitis B virus infection in patients with positive or negative $H$. pylori infection was evaluated. The study involved 728 patients who underwent endoscopy in 2017-2018. Histopathological analysis of tissues was performed on samples taken from the stomach [92]. The presence of HBsAg in the serum of the examined patients was confirmed by the immunoenzymatic method (ELISA). The relationship between gastric cancer and HBV infection was examined using logistic regression analysis. From the results obtained, it appears that among 728 patients, HBsAg infection was detected in $83(11.4 \%)$, while H. pylori infection was confirmed in 408 (56\%) patients. Co-infection with $H$. pylori/HBV was confirmed in 69 (9.5\%) patients [92]. Helicobacter pylori infection was significantly more frequently detected in patients with positive HBsAg than negative $(p=0.029)$ [92]. Not a single patient co-infected with $H$. pylori/HBV had normal stomach tissue. There was a significant histopathological difference in gastric tissue between patients with HBsAg positive and no H. pylori infection $(p<0.0001)$. The hepatitis B surface antigen (HBsAg) was associated with histopathological changes in stomach tissue $(\mathrm{OR}=21.56,95 \% \mathrm{CI}=7.070-65.741, p<0.001)$ and may be a potential risk factor for gastritis $(\mathrm{OR}=12.457,95 \% \mathrm{CI}=3.007-51.614, p=0.001)$ [92]. The effect of HBsAg infection on the development of stomach cancer was not confirmed (OR $=2.127$, $95 \% \mathrm{CI}=0.242-18.704, p=0.496)$. Baghbanian et al. [92] concluded that HBV infection alone may be associated with some precancerous lesions, but is not correlated with gastric cancer. In contrast, the hepatitis B virus, in the case of people with Helicobacter pylori infection, can significantly affect the severity of precancerous conditions or the development of gastric cancer [92].

\subsection{Hepatitis C Virus}

Hepatitis $\mathrm{C}$ virus (HCV) is a human, single-stranded, linear RNA virus with positive (+) ssRNA polarity and a length of about $9.6 \mathrm{kbp}$ [108-110]. The virus belongs to the family Flaviviridae of the genus Hepacivirus [23]. It is estimated that around 171 million people worldwide are constantly infected with HCV, which causes a number of chronic liver diseases $[110,111]$. Hepatitis C virus, like hepatitis $B$ virus, has a natural tropism to the liver and contributes to hepatocellular carcinoma (HCC) and gallbladder cancer $[8,110]$.

In the case of HCV, both the core and the unstructured protein 5A (NS5A) and NS3 directly promote the development of hepatocellular carcinoma, by altering the expression of the host gene, and inflammation caused by the immune system indirectly affects the formation of tumors $[112,113]$. The HCV core and the NS3 and NS5A proteins promote the proliferation of liver cells through the $\beta$-catenin pathway. The core protein affects the expression of cyclin-dependent kinase 2 (cdk2) and cyclin E [100,114].

The HCV, as with the HBV, avoids growth suppression and immune destruction by inhibiting the apoptosis process [114]. HCV infection induces innate immunity, but viral proteins effectively block signaling that triggers IFN $\beta$ (interferon beta) as well as IFN $\alpha$ (interferon alpha) signaling by targeting JAK/STAT [100]. The HCV core and NS3 protein inactivate many suppressor genes [100]. The core blocks the process of apoptosis by inhibiting caspase 8 using the host's immune system $[100,112,114]$. Binding of NS5A to signaling cellular molecules inhibits the immune response, suppressor genes and apoptosis $[98,115]$. The HCV virus up-regulates miR-181, which causes the appearance of "stemness" markers in hepatocellular carcinoma [100]. One of the features of HCV-associated cancers is replication immortality. In the case of hepatitis $C$ virus, stable transfection of human hepatocytes with the HCV core promotes differentiation, continuous growth and increased expression of telomerase, which can largely promote immortality [100].

The HCV has the ability to trigger an angiogenesis process. This process is caused by the production of a large amount of ROS, which affect the activation of a number of HIF1 $\alpha$ stabilizing signaling pathways [115]. 
Malignant strains of HCC have a predisposition to invade and metastasize. This is caused by elevated levels of the HGF receptor (hepatocyte growth factor) and c-met. These factors can lead to diffusion, angiogenesis, proliferation and increased cellular motility, eventually to invasion and metastasis [100]. The HCV core causes EMT (epithelial-mesenchymal transition) and tumor invasion. By activating JNK/pSmad3L signaling, the core protein abolishes TGF $\beta$-dependent tumor suppression [115].

DNA repair and apoptosis are also regulated by poly (ADP-ribose) polymerase 1 (PARP-1). The NS5A protein stabilizes PARP-1 levels by blocking caspase 3-mediated cleavage. These processes may allow mutation reproduction and genetic instability in cells infected with HCV $[100,115]$.

Patients infected with HCV have a higher risk of developing hepatocellular carcinoma compared to those who are not infected. Unlike HBV, which has the ability to integrate into the host genome, thereby causing direct carcinogenic activation, it is known that $\mathrm{HCV}$ is an RNA virus that has limited ability to integrate its genetic information into the host genome. Therefore, hepatitis c virus carcinogenicity is associated with indirect mechanisms [116]. In total, HCV and HBV caused 433,186 new liver cancer cases and 406,779 deaths in 2012 , which is $77.61 \%$ of liver cancer cases and $76.6 \%$ of deaths [8]. There are no data to date regarding the impact of $\mathrm{HCV}$ on the development of gastric cancer.

\subsection{HTLV-1}

Human T-lymphocytes lymphoma virus-1 is a member of Retroviridae [23]. The association of human T-cell lymphotroptic virus 1 with cancer is controversial, and positive correlation was confirmed in case of human leukemia $[117,118]$. Transmission of the virus is possible through sexual intercourse, breastfeeding and contaminated blood [119]. First line of infection with the virus are DCs (dendritic cells), afterwards HTLV-1 may be transmitted to CD4 ${ }^{+}$T cells and, to a lesser extent, CD8 ${ }^{+}$lymphocytes, B cells and monocytes [119]. It is worth mentioning that viral spread of HTLV-1 is dependent on cell-to-cell contact, but also forming a viral biofilm or virological synapse $[120,121]$. Other possible spreading mechanisms may include nanotubes [122]. The latest data show that the promotion of cell-to-cell contact may be influenced by the formation of extracellular vesicles, to elicit adverse effects on recipient uninfected cells [123].

Oncogenic mechanisms are not evident for HTLV-1, nevertheless, a crucial role may be performed by the regulatory proteins Tax and HBZ with oncogenic properties [119,124]. Tax is a trans-acing viral protein being a major target of CTLs (cytotoxic lymphocytes), and its mechanism of transformation is related to reprogramming cell cycle and the inhibition of DNA repair [19], while HBZ is a leucine zipper factor with low immunogenicity, suppressing major HTLV-1 genes, possessing a role in cell proliferation, apoptosis, T-cell differentiation and immune escape [125]. Moreover, the differences in oncogenic mechanism may also result from the alterations of the infected cell microenvironment [123]. Additionally, similarly to other oncogenic viruses, the infection favors chronic infection, leading to immunosuppression and cancer development [124]. In blood malignancies it was confirmed, that one of the oncogenic mechanisms involving HTLV-1 infection is the dysregulation of gene expression, leading to abnormal chromatin looping, changing the position of HTLV-1 promoter-enhancer position [126].

Studies have been performed in the association of HTLV-1 with gastric cancer, leading to the conclusion, that the prevalence of HTLV-1 infection in patients with gastric cancer appears to be significantly lower than that in control patients [127-129]. Additionally, HTLV-1 reduces the risk of Helicobacter pylori infection, thus indirectly, influences the lower rate of gastric cancer, as $H$. pylori infection is known to be a frequent risk factor of this type of cancer [128].

\subsection{Human Immunodeficiency Virus}

Human immunodeficiency virus (HIV) is single-stranded RNA virus with positive (+) ssRNA polarity [130], belonging to the family Retroviridae of the genus Lentivirus [23]. So far, two types of HIV have been distinguished-HIV-1 and HIV-2 [130]. Both types of virus evolved from two different viruses attacking monkeys-SIV (Simian immunodeficiency virus) [130]. 
HIV infection leads to serious changes that disrupt the immune system of the host, making it extremely susceptible to other viral, bacterial and fungal infections. This condition was called acquired immune deficiency syndrome-AIDS [131]. Most often, HIV infection occurs through sexual contact, but also this virus can get into the bloodstream through contaminated needles or perinatally from an infected mother [131]. In most cases, untreated HIV infections lead to death $[130,131]$. The HIV virus, by weakening the host's immune system, reduces the body's ability to defend itself effectively and combat viral infections leading to the development of cancer [132]. An organism without defense becomes an excellent environment that allows the free development of other oncogenic viruses such as KSHV, EBV, HPV, HBV, HCV and HTLV-1 [133].

The HIV virus may have oncogenic potential through direct cellular mechanisms mediated primarily by the HIV Tat protein [134]. The Tat protein is an early unstructured protein, essential for viral replication [135]. Tat HIV is released from HIV-1 infected cells. The protein can bind to uninfected cells, including endothelial cells, and infiltrate through the domain of protein transduction [136]. The Tat HIV protein can affect the blocking of the tumor suppressor gene function as well as activate proto-oncogenes, inhibit apoptosis and affect cell cycle progression [134].

People infected with HIV have a higher risk of certain types of cancer than people of the same age who have not been found to be infected with HIV [137]. The HIV virus mainly contributes to the development of Kaposi's sarcoma, aggressive B-cell non-Hodgkin's lymphoma and cervical cancer [132]. These cancers are referred to as "acquired immunodeficiency syndrome (AIDs)-defining cancers" or "AIDS-defining malignancies". Diagnosing each of these three cancers in people who are positive for HIV confirms the diagnosis of AIDS [132].

In addition, it has been observed that HIV infection can lead to the development of other cancers known as non-AIDS-defining cancers, such as cancers of the anus, penis, liver, oral cavity/pharynx and lung, and Hodgkin lymphoma [137-140].

To date, no confirmed involvement of HIV-1 in gastric cancer has been reported. In 2012, Perrson et al. presented the study, which showed that the risk of gastric cancer was significantly increased among patients with confirmed AIDS (SIR $=1.44 ; 95 \% \mathrm{CI}, 1.17-1.76)$ [141]. For the general population, the incidence rate for stomach cancer was 5.00 per 100,000 person-years [141]. Unfortunately, in 2016, this article was withdrawn due to irregularities in statistical surveys. As a result of errors, standardized incidence ratios (SIRs) were too high. SIR corrected results are lower than the authors reported, and corrected SIR for gastric cancer is no longer significantly increased [142].

\section{Adenovirus-Oncogenic or Oncolytic?}

The role of adenoviruses in gastric cancer is mysterious. On one hand, adenoviruses (Adenoviridae) [23] are known to be oncogenic in many malignances [143,144], but the oncolytic properties of the virus also exist. In the case of gastric cancer, only oncolytic properties have been used in several studies in order to improve the possibilities of therapies. For effective oncolytic activity, adenoviruses must specifically infect and replicate within cancer cells, but unfortunately, many malignant cells do not express the CAR receptor (coxsackie and adenovirus receptor), resulting in decreased transduction of serotype $5 \mathrm{Ad}$ (Ad5), which is commonly used for Ad-based vectors [145]. Therefore, efforts are made, to modify Ad5 fibers, the capsid moiety responsible for virus-cell surface receptor interaction, in order to increase their transduction to cancer cells [145]. It is also known, that adenovirus vector has a capacity to produce high titers and is genomically stable, with a low rate of DNA integration into the host's genome [146]. On the other hand, adenovirus vectors may induce potent immunogenic toxicities, followed by the inhibition of the expression of transgene mediated by the vector itself, leading to several limitations of this kind on cancer therapy, so the good and the bad face of the virus treatment is here also as an issue [147]. In gastric cancer, adenovirus vectors have also been used [148]. There are reports about oncolytic adenoviral vectors, in which modification has been made, by replacing E1a and E1b promoters of adenovirus with human telomerase reverse transcriptase (hTERT) and hypoxia response element (HRE) promoters, leading to creation of recombinant oncolytic 
adenovirus KGHV [148]. The study by Wang et al. [148] shows that the infection of normal cells may be decreased by the combination of KGHV500 adenovirus, targeted at CIK (cytokine-induced killer cells), with a known anticancer potential [148]. This leads to the conclusion, that such way of delivering oncolytic viruses to tumor targets are a promising method.

Additionally, tumor-specific midkine and cyclooxygenases (Cox2M and Cox $2 \mathrm{~L}$ ) promoters were tested in gastric cancer, and high activity was noted with oncolytic effect was confirmed for Cox2CR-Ad complex and fiber-modified vector Ad5/3 [149].

There is also a study showing, that adenovirus bound as a vector with Arg-Gly-Asp peptides in the fiber knob, allowed the virus to utilize integrins, which is a very promising target, while integrins are highly expressed in gastric cancer [143].

In another study, a CEA promoter was introduced into an adenovirus vector, and this method was also a successful attempt at decreasing the number of gastric carcinoma cells [150].

A broad study was also conducted on the role of adenovirus and the correlation of it with TIPE2 expression. TIPE2 is tumor necrosis factor-alpha induced protein 8-like 2 downregulating innate immunity via impacting on TLR signaling, macrophages and dendritic cells [151]. It was shown that TIPE2 is reduced or absent in several tumors, including gastric cancer [144,152]. TIPE2 is an inhibitor of gastric cancer cell growth, and might promote a p27-associated signaling cascade that leads to control the cell cycle and cell division, leading to the conclusion, that TIPE2 may regulate proliferation of gastric cells [152]. Moreover, according to Zhu et al. [146], TIPE2 may be a novel potential therapeutic target for human gastric cancer, on the basis of the results achieved in a panel of human gastric cells (AGS, HGC-27 and SGC-7901), where expression of TIPE2 was lost. Adenovirus-mediated human TIPE2 overexpression significantly inhibited AGS and HGC-27 gastric cancer cell growth and induced AGS and HGC-27 tumor cell apoptosis in vitro [146]. Further investigations showed [151], that adenovirus-mediated TIPE2 upregulate E-cadherin epithelial marker in AGS and HGC-27 in in vitro and in vivo model, leading to the conclusion, that TIPE2 not only inhibits gastric cancer cell migration, but also stating that invasion and metastasis in gastric cancer in probably via reversal of epithelial-mesenchymal transition, which may be crucial in further therapeutic approaches [151].

Adenovirus vector was also targeted at cancer associated fibroblasts (CAF), being the crucial microenvironment of tumor growth, invasion and metastasis [147]. CAFs contribute to cancer growth and metastasis by secreting cytokines, growth factors and adhesion molecules, leading to enhancement of radio and chemotherapy resistance, that is why CAFs seem to be a potentially successful target for cancer therapy via adenovirus vectors [147]. Such studies have been also performed in relation to gastric cancer, and it was concluded, that fiber-modified hexon-chimeric recombinant oncolytic adenovirus targeting CAFs can kill gastric CAFs and inhibit gastric cancer growth in vivo [147].

On the basis of the fact, that most cancer cells are characterized with an increased telomerase activity, studied have been performed with telomerase-specific oncolytic adenovirus, which can suppress tumor cells, not influencing the healthy ones [153]. This was also confirmed in studies on gastric cancer cells in vitro, by combining tumor-specific TRAIL (tumor necrosis factor-related apoptosis-inducing ligand) with adenovirus vector [146]. Moreover, this type of novel therapeutic approach was noted to be successful even in advance stage of gastric cancer with peritoneal dissemination [146].

\section{Oncolytic Viruses}

Oncolytic viruses are promising cancer gene therapy agents, as they have the ability to selectively replicate in cancer cells, causing cancer cell lysis and inflammation, leading to the stimulation of host immune responses to cancer cells [4].

Oncolytic viruses are successfully used in cancer immunotherapy, as they target multiple steps within the cancer-immunity cycle $[154,155]$. The ability of viruses to attack cancer cells was discovered in the mid-20th century [156,157], but the first clinical trials documenting the actual clinical benefits of using oncolytic viruses have been carried out over the last 15 years [154]. Currently, with increasing knowledge about viruses in general and the constant development of research and therapeutic 
techniques, the interest in viruses as factors used in cancer immunotherapy is constantly growing. Many research teams are working on the development of optimized therapy with viruses. At this point in time, the only oncolytic viruses approved for cancer therapy are: Talimogene laherparepvec (T-VEC) approved by the FDA in 2017 [158] and genetically modified adenovirus H101 approved in 2006 in China [159]. The former was approved as immunotherapy for patients with advanced melanoma, the latter for treating head and neck cancer. These are huge successes in cancer therapy and are likely to significantly contribute to the development of this field of immunotherapy. Some other trials are still ongoing, like the one using the measles virus TMV-018 (ClinicalTrials.gov.NCT04195373), or vaccinia viral oncolytic vector (GL-ONC1; ClinicalTrials.gov.NCT01443260).

The mechanism of action of oncolytic viruses may be different. They may lead to direct lysis of cancer cells, leading to the release of soluble antigens, danger signals and type I interferons, which drive antitumour immunity. Furthermore, some oncolytic viruses may be created artificially to express therapeutic genes. They can also alter tumor-related endothelial cells, which increases the recruitment of $\mathrm{T}$ lymphocytes into excluded or immunocompromised tumor microenvironments. Ultimately, oncolytic viruses can also be used as a source of in situ neoantigenic vaccinations through their cross-presentation, which leads to distant uninfected tumors [155].

These features make scientists willing to study the efficacy of oncolytic viruses. However, further studies are necessary to develop better therapies using them.

There are several oncolytic viruses (Table 3), and they are divided into two classes-firstly viruses that naturally replicate in cancer cells and are usually mild in human infection, such as parvoviruses, myxoma virus (MYXV), Newcastle disease virus (NDV), reovirus and Seneca valley virus (SVV) [160]. Second class contains viruses that are genetically changed and used as vectors, including measles virus (MV), poliovirus (PV) and vaccinia virus (VV) [160]. In this group, also genetically-engineered viruses are included, characterized by mutations in genes required for replication in normal conditions, and among such viruses, adenovirus, herpes simplex virus (HSV) and vesicular stomatitis virus (VSV) are enumerated [160]. The last group seems to be of special interest, not only due to the potential in cancer therapies, but also because of being a double-edged sword in this matter, and those viruses will be discussed, excluding adenovirus, placed as a puzzle between oncogenic and oncolytic viruses in gastric cancer.

Table 3. Oncolytic viruses.

\begin{tabular}{ccc}
\hline Family & Virus & References \\
\hline Adenoviridae & 1. DNA viruses & \\
\hline Herpesviridae & Adenovirus $^{1}$ & {$[161-168]$} \\
\hline Parvoviridae & Herpes simplex virus $^{2}$ & {$[161-164,167,168]$} \\
\hline \multirow{2}{*}{ Poxviridae } & Parvovirus & {$[163,168-170]$} \\
\cline { 2 - 3 } & Myxoma virus & {$[168,171]$} \\
\hline Orthomyxoviridae & Vaccinia virus & {$[161-164,167,168,171]$} \\
\hline & 2. RNA viruses & {$[168,172]$} \\
\hline Paramyxoviridae & Influenza virus & {$[161-164,167,168,171,172]$} \\
\cline { 2 - 3 } & Measles virus & {$[161-164,166,168,170,172]$} \\
\hline
\end{tabular}


Table 3. Cont.

\begin{tabular}{ccc}
\hline Family & Virus & References \\
\hline \multirow{3}{*}{ Picornaviridae } & Coxsackievirus & {$[161,163,166-168,171]$} \\
\cline { 2 - 3 } & Echovirus & {$[161,166,167]$} \\
\cline { 2 - 3 } & Encephalomyocarditis virus and Mengovirus & {$[167]$} \\
\cline { 2 - 3 } & Seneca valley virus & {$[166,167]$} \\
\cline { 2 - 3 } & Theiler's Murine Encephalomyelitis Virus & {$[163,165-167]$} \\
\hline Reoviridae & Reovirus & {$[167]$} \\
\hline Retroviridae & Retrovirus & {$[161-164,166-168,170-172]$} \\
\hline \multirow{2}{*}{ Rhabdoviridae } & Maraba virus & {$[161,163,169]$} \\
\cline { 2 - 3 } & & {$[161-164,167,168,172]$} \\
\hline
\end{tabular}

1-approved in China; 2-approved in USA.

\section{Oncolytic Viruses and the Immune System}

During the infection with an oncolytic virus, a panel of immune cells is recruited, from both innate and adaptive immune signaling (Figure 2). After recognition by anti-viral PRRs (mainly TLRs and RIG-1), the production of pro-inflammatory cytokines and interferons takes place. Neutrophils and macrophages release several inflammatory mediators, cationic proteins, lipid mediators, metalloproteinases and components of oxygen burst [18]. Additionally, DC and NK (natural killer) are triggered and the virus is presented to the panel of $\mathrm{T}$ cells- $\mathrm{T}$ helper cells responses are induced, followed by CTL killing of the virally infected cells and causing tissue damage. Additionally, $\mathrm{T}_{\mathrm{H}} 17$ contribute to an inflammatory response. The process is impaired by Treg. Finally, $\mathrm{B}$ cells are activated to antibodies production [18].

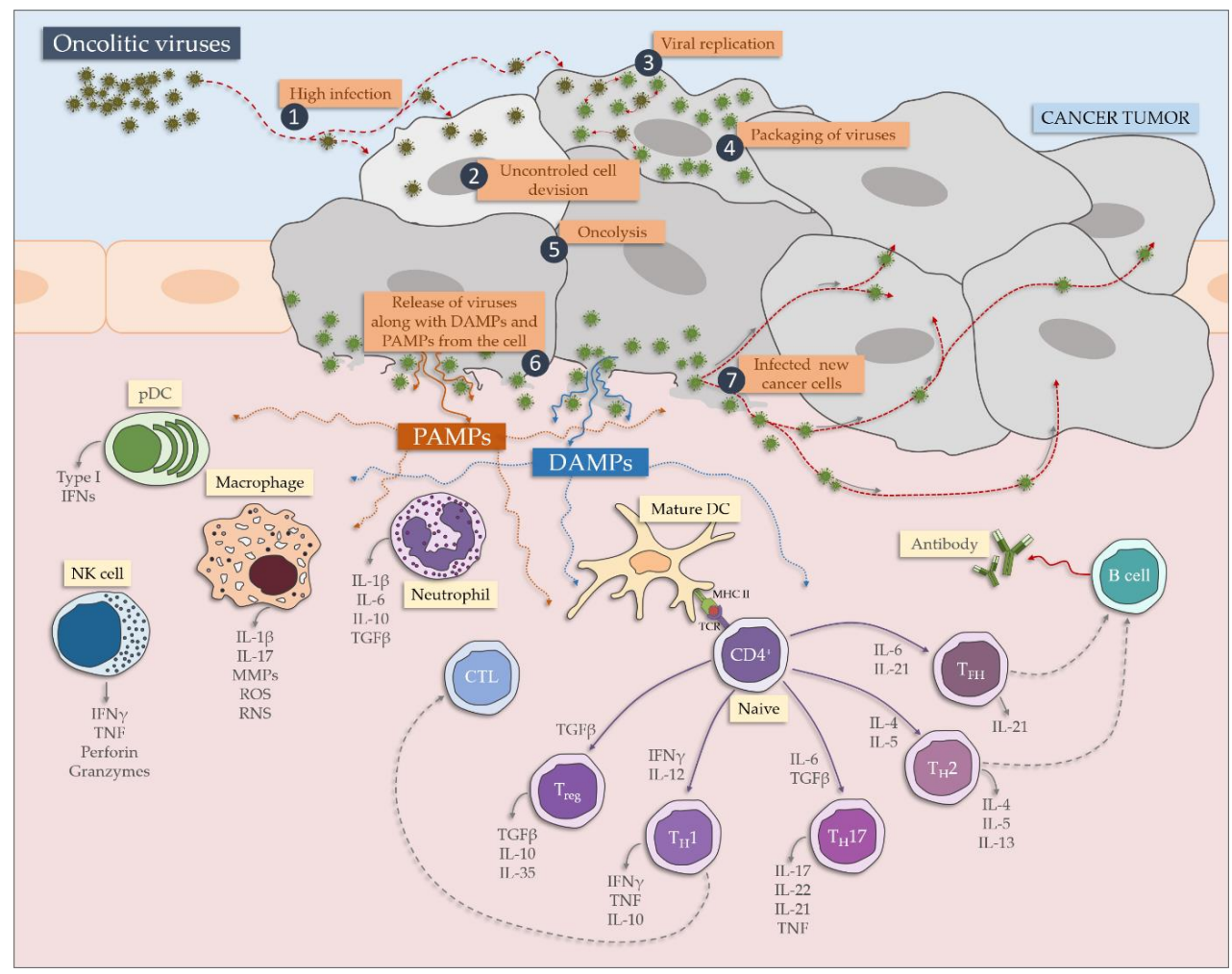

Figure 2. The impact on oncolytic viruses on the immune system. 


\section{Oncolytic Viruses in Gastric Cancer}

\subsection{Herpes Simplex Virus}

HSV, a member of Herpesviridae [23], is an enveloped ds linear DNA virus, with genes classified into three groups by the regulation of their expression-immediate early (IE), early (E) and late (L) [174]. The IE gene products regulate gene transcription and include the US12 gene product, which is ICP47-responsible for silencing MHC I expression in infected cells via inhibition of TAP (transporter associated with antigen presentation) [174]. The E genes promote viral DNA synthesis and the L genes are coding capsid proteins, tegument proteins and envelope glycoproteins [174].

One of the advantages of using HSV in oncolytic virotherapy is the fact, that this virus can bind only to a single receptor, which gives the opportunity to use it in treatments of many malignancies, due to the existence of four cellular receptors on HSV [174]. Moreover, HSV, due to its large genome, is able to incorporate a large size of a foreign DNA, the infection may be quite easily controlled with anti-herpetic drugs and can kill target cell faster and more effectively comparing to adenovirus [174,175]. Among genes important for effective oncolysis, ICP0, ICP4 and ICP47 are enumerated, but it is worth adding, that some of this data is more than ten years old now [174].

There are several HSV strategies to avoid the host's immune response, including complementing immunoglobulins via viral glycoproteins, inhibition of cytokine production, blocking the maturation of APC (antigen presenting cells), expression of MHC II, inhibiting apoptosis and cell death induced by CTL (cytotoxic lymphocytes) [175].

Several oncolytic mutants of HSV are in different stages of clinical trials on solid tumors with a high level of success [176]. However, their efficacy depends on the extent of both intratumoral viral replication and induction of a host antitumor immune response [175]. Such an immune response may induce the upregulation of angiogenic factors and downregulation of antiangiogenic factors, such as thrombospondin-1 (TSP-1), but some moderations are made to increase the oncolytic action of the virus [176]. In studies of Tsuji et al. [176], replication-competent oncolytic HSV was constructed as a vector to deliver TSP-1 to a gastric cancer microenvironment, and this enhanced antitumor efficacy in vitro and in vivo via direct antitumor and antiangiogenic mechanisms. Moreover, in gastric tumor cell line SGC7901, the synergistic antitumor effect of herpes virus thymidine kinase (HSV-TK) with TNF- $\alpha$ and IL-2 gene expression was evaluated, but with no significant effect [177]. On the other hand, other studies on mice model showed a therapeutic effect of HSV-TK expression [178], so further studies are needed in this matter.

Additionally, in gastric cancer, two multimutant oncolytic herpes simplex viruses of the second generation-G207 and NV1020 - have been shown to kill in vitro human gastric cancer cells [179]. With the use of a murine xenograft model of peritoneally disseminated gastric cancer, it was registered, that with lower viral dose NV1020 was more effective comparing to G207, but intraperitoneal administration was crucial for the positive effect [179]. Those safe for animal pre-clinical trials are a promising pathway for successful treatment of gastric cancer. Additionally, studies were conducted in which G207 was combined with mitomycin C (MMC) and significant synergism was observed [180]. This combination upregulated GADD34 in tumor and thus may complement the gamma134.5 gene deletion in gastric human cells in vitro [180].

Moreover, preclinical trials have been conducted with the use of third generation oncolytic HSV-1-G47A, which is a triple mutated virus developed by adding another deletion mutation to the genome of a second-generation HSV-1-G207 [181]. The use of this virus in GC (gastric cancer) decreased the level of M2 macrophages and increased the level of M1 macrophages and NK cells [181]. Interestingly, a strong antiviral response was reported leading to a controversial conclusion that innate immunity stimulated by oncolytic virus treatment may facilitate the priming of antitumor immunity [181]. 


\subsection{Vesicular Stomatitis Virus (VSV)}

Vesicular stomatitis virus, a member of the Rhabdoviridae family [23], is known to be replicating to induce apoptosis of many types of cells, including cancer cells, but only one report exists on the role of VSV in gastric cancer [182]. In gastric carcinoma cell line MKN28, the expression of vesicular stomatitis virus matrix protein (MP) was confirmed to inhibit proliferation and induce apoptosis on this type of cancer cell [182].

\subsection{Vaccinia Virus}

Vaccinia virus, a member of the Poxviridae family [23], may also be an attractive potential oncolytic virus for GC treatment, as stated above, even a clinical trial is ongoing-phase I and II completed, with the use of this virus (NCT01443260). Among the advantages of this virus, as far as genetic engineering is concerned, one can enumerate the ability to incorporate large amounts of foreign DNA without losing the replication efficiency and high safety in humans [183]. GLV-1 h153, which is a genetically engineered vaccinia virus carrying the human sodium iodide symporter (hNIS) gene, was tested as a potential and novel therapy against GC [183]. It was shown [183] that GLV-1 $\mathrm{j} 153$ is an effective oncolytic virus giving successful results in five human gastric cancer lines, giving over $90 \%$ cytotoxicity. This promising result may also be enhanced by the combination of treatment with GLV-1 h153 and radioiodine, which needs to be further studied [183].

\section{Conclusions}

Searching for an efficient and effective cancer treatment is one of the key interests in today's world. Gastric cancer, no matter the downward trend, is still a major concern, and expanding treatment possibilities is a pivotal issue. Oncolytic virotherapy is surely one of the options. On the other hand, oncogenic role of viruses has been also known and is proven in gastric cancer. Showing a double-edge sword face of viruses in gastric cancer aimed at drawing the attention to a cautious choice of cancer treatment.

Author Contributions: P.N.-R., E.G.; conceptualization, P.N.-R., E.G., R.H., M.W., R.B.; writing一original draft preparation; P.N.-R., E.G., R.H., M.W., J.R.; writing-review and editing. All authors have read and agreed to the published version of the manuscript.

Funding: This research was funded by the Polish National Science Center, grant no. UMO-2016/21/B/NZ6/02279 and the Medical University of Lublin, grants no. DS460 and DS461.

Conflicts of Interest: The authors declare no conflict of interest.

\section{References}

1. International Agency for Research on Cancer. Globocan 2018. Cancer Incidence and Mortality Statistics Worldwide in 2018. Available online: https:/gco.iarc.fr/today/data/factsheets/cancers/7-Stomach-fact-sheet. pdf (accessed on 23 May 2020).

2. International Agency for Research on Cancer. Globocan 2018. Available online: http://gco.iarc.fr/ (accessed on 23 May 2020).

3. Zapatka, M.; Borozan, I.; Brewer, D.S.; Iskar, M.; Grundhoff, A.; Alawi, M.; Desai, N.; Sültmann, H.; Moch, H.; Cooper, C.S.; et al. The landscape of viral associations in human cancers; PCAWG Consortium. Nat. Genet. 2020, 52, 320-330. [CrossRef] [PubMed]

4. Lichty, B.D.; Breitbach, C.J.; Stojdl, D.F.; Bell, J.C. Going viral with cancer immunotherapy. Nat. Rev. Cancer 2014, 14, 559-567. [CrossRef] [PubMed]

5. Şevik, M. Oncogenic viruses and mechanisms of oncogenesis. Turk. J. Vet. Anim. Sci. 2012, 36, $323-329$. [CrossRef]

6. Chang, Y.; Moore, P.S.; Weiss, R.A. Human oncogenic viruses: Nature and discovery. Philos. Trans. R. Soc. 2017, 372, 20160264. [CrossRef] [PubMed]

7. Jha, H.C.; Banerjee, S.; Robertson, E.S. The Role of Gammaherpesviruses in Cancer Pathogenesis. Pathogens 2016, 5, 18. [CrossRef] [PubMed] 
8. Huang, H.; Hu, X.-F.; Zhao, F.-H.; Garland, S.M.; Bhatla, N.; Qiao, Y.-L. Estimation of Cancer Burden Attributable to Infection in Asia. J. Epidemiol. 2015, 25, 626-638. [CrossRef]

9. Zheng, Z.M. Viral oncogenes, noncoding RNAs, and RNA splicing in human tumor viruses. Int. J. Biol. Sci. 2010, 6, 730-755. [CrossRef]

10. Chen, Y.; Williams, V.; Filippova, M.; Filippov, V.; Duerksen-Hughes, P. Viral carcinogenesis: Factors inducting DNA damage and virus integration. Cancers 2014, 6, 2155-2186. [CrossRef]

11. De Flora, S.; Bonanni, P. The prevention of infection-associated cancers. Carcinogenesis 2011, 32, 787-795. [CrossRef]

12. Chen, C.J.; Hsu, W.L.; Yang, H.I.; Lee, M.-H.; Chen, H.-C.; Chien, Y.-C.; You, S.-L. Epidemiology of virus infection and human cancer. Recent Results Cancer Res. 2014, 193, 11-32. [CrossRef]

13. de Souza, C.; Almeida, M.; Khayat, A.S.; da Silva, E.L.; Soares, P.C.; Chaves, L.C.; Burbano, R. Association between Helicobacter pylori, Epstein-Barr virus, human papillomavirus and gastric adenocarcinomas. World J. Gastroenterol. 2018, 24, 4928-4938. [CrossRef] [PubMed]

14. Thompson, M.P.; Kurzrock, R. Epstein-Barr Virus and Cancer. Clin. Cancer Res. 2004, 10, 803-821. [CrossRef]

15. Ayee, R.; Ofori, M.E.O.; Wright, E.; Quaye, O. Epstein Barr Virus Associated Lymphomas and Epithelia Cancers in Humans. J. Cancer 2020, 11, 1737-1750. [CrossRef]

16. Haley, C.T.; Mui, U.N.; Vangipuram, R.; Rady, P.L.; Tyring, S.K. Human oncoviruses: Mucocutaneous manifestations, pathogenesis, therapeutics, and prevention: Papillomaviruses and Merkel cell polyomavirus. J. Am. Acad. Dermatol. 2019, 81, 1-21. [CrossRef] [PubMed]

17. Zeng, Z.M.; Luo, F.F.; Zou, L.X.; He, R.Q.; Pan, D.H.; Chen, X.; Xie, T.T.; Li, Y.Q.; Peng, Z.G.; Chen, G. Human papillomavirus as a potential risk factor for gastric cancer: A meta-analysis of 1,917 cases. Onco. Targets Ther. 2016, 9, 7105-7114. [CrossRef]

18. Rouse, B.T.; Sehrawat, S. Immunity and immunopathology to viruses: What decides the outcome? Nat. Rev. Immunol. 2010, 10, 514-526. [CrossRef] [PubMed]

19. Morales-Sanchez, A.; Fuentes-Panana, E.M. Human viruses and cancer. Viruses 2014, 6, 4047-4079. [CrossRef]

20. Kuss-Duerkop, S.K.; Westrich, J.A.; Pyeon, D. DNA tumor virus regulation of host DNA methylation and its implications for immune evasion and oncogenesis. Viruses 2018, 10, 82. [CrossRef]

21. Krump, N.A.; You, J. Molecular mechanisms of viral oncogenesis in humans. Nat. Rev. Microbiol. 2018, 16, 684-698. [CrossRef]

22. Gallo, A.; Miceli, V.; Bulati, M.; Iannolo, G.; Contino, F.; Conaldi, P.G. Viral miRNAs as active players and participants in tumorigenesis. Cancers 2020, 12, 358. [CrossRef]

23. International Committee on Taxonomy of Viruses (ICTV). Taxonomy. Available online: https://talk.ictvonline. org/taxonomy/ (accessed on 25 May 2020).

24. Bogolyubova, A.V. Human Oncogenic Viruses: Old Facts and New Hypotheses. Mol. Biol. (Mosk) 2019, 53, 767-775. [CrossRef]

25. Sample, J.; Young, L.; Martin, B.; Chatman, T.; Kieff, E.; Rickinson, A.; Kieff, E. Epstein-Barr virus types 1 and 2 differ in their EBNA-3A, EBNA-3B, and EBNA-3C genes. J. Virol. 1990, 64, 4084-4092. [CrossRef] [PubMed]

26. Damania, B. DNA tumor viruses and human cancer. Trends Microbiol. 2007, 15, 38-44. [CrossRef] [PubMed]

27. Nilsson, K.; Klein, G.; Henle, W.; Henle, G. The establishment of lymphoblastoid lines from adult and fetal human lymphoid tissue and its dependence on EBV. Int. J. Cancer 1971, 8, 443-450. [CrossRef] [PubMed]

28. Rickinson, A.; Kieff, E. Epstein-Barr virus. Fields Virology, 4th ed.; Knipe, D.M., Howley, P.M., Eds.; Lippincott Williams \& Wilkins: Philadelfia, PA, USA, 2001; pp. 2575-2627.

29. Mosialos, G.; Birkenbach, M.; Yalamanchil, R.; VanArsdale, T.; Ware, C.; Kieff, E. The Epstein-Barr virus transforming protein LMP1 engages signaling proteins for the tumor necrosis factor receptor family. Cell 1995, 80, 389-399. [CrossRef]

30. Zhang, L.; Pagano, J.S. Interferon regulatory factor 7 is induced by Epstein-Barr virus latent membrane protein 1. J. Virol. 2000, 74, 1061-1068. [CrossRef]

31. Wakisaka, N.; Murono, S.; Yoshizaki, T.; Furukawa, M.; Pagano, J.S. Epstein-barr virus latent membrane protein 1 induces and causes release of fibroblast growth factor-2. Cancer Res. 2002, 62, 6337-6344.

32. Miller, C.L.; Lee, J.H.; Kieff, E.; Longnecker, R. An integral membrane protein (LMP2) blocks reactivation of Epstein-Barr virus from latency following surface immunoglobulin crosslinking. Proc. Natl. Acad. Sci. USA 1994, 91, 772-776. [CrossRef] 
33. Dykstra, M.L.; Longnecker, R.; Pierce, S.K. Epstein-Barr virus coopts lipid rafts to block the signaling and antigen transport functions of the BCR. Immunity 2001, 14, 57-67. [CrossRef]

34. Cohen, J.I.; Kieff, E. An Epstein-Barr virus nuclear protein 2 domain essential for transformation is a direct transcriptional activator. J. Virol. 1991, 65, 5880-5885. [CrossRef]

35. Tomkinson, B.; Kieff, E. Second-site homologous recombination in Epstein-Barr virus: Insertion of type 1 EBNA 3 genes in place of type 2 has no effect on in vitro infection. J. Virol. 1992, 66, 780-789. [CrossRef]

36. Vereide, D.; Sugden, B. Insights into the evolution of lymphomas induced by Epstein-Barr virus. Adv. Cancer Res. 2010, 108, 1-19. [CrossRef]

37. Vereide, D.T.; Sugden, B. Lymphomas differ in their dependence on Epstein-Barr virus. Blood 2011, 117, 1977-1985. [CrossRef]

38. Jha, H.C.; Pei, Y.; Robertson, E.S. Epstein-Barr Virus: Diseases Linked to Infection and Transformation. Front. Microbiol. 2016, 7, 1602. [CrossRef]

39. Wołącewicz, M.; Becht, R.; Grywalska, E.; Niedźwiedzka-Rystwej, P. Herpseviruses in Head and Neck cancers. Viruses 2020, 12, 172. [CrossRef] [PubMed]

40. Shibata, D.; Tokunaga, M.; Uemura, Y.; Sato, E.; Tanaka, S.; Weiss, L.M. Association of Epstein-Barr virus with undifferentiated gastric carcinomas with intense lymphoid infiltration. Lymphoepithelioma-like carcinoma. Am. J. Pathol. 1991, 139, 469-474. [PubMed]

41. Tokunaga, M.; Land, C.E.; Uemura, Y.; Tokudome, T.; Tanaka, S.; Sato, E. Epstein-Barr virus in gastric carcinoma. Am. J. Pathol. 1993, 143, 1250-1254. [PubMed]

42. Nishikawa, J.; Yoshiyama, H.; Iizasa, H.; Kanehiro, Y.; Nakamura, M.; Nishimura, J.; Saito, M.; Okamoto, T.; Sakai, K.; Suehiro, Y.; et al. Epstein-barr virus in gastric carcinoma. Cancers 2014, 6, 2259-2274. [CrossRef]

43. Nishikawa, J.; Iizasa, H.; Yoshiyama, H.; Nakamura, M.; Saito, M.; Sasaki, S.; Shimokuri, K.; Yanagihara, M.; Sakai, K.; Suehiro, Y.; et al. The Role of Epigenetic Regulation in Epstein-Barr Virus-Associated Gastric Cancer. Int. J. Mol. Sci. 2017, 18, 1606. [CrossRef] [PubMed]

44. Chen, X.Z.; Chen, H.; Castro, F.A.; Hu, J.K.; Brenner, H. Epstein-Barr virus infection and gastric cancer: A systematic review. Medicine 2015, 94, e792. [CrossRef] [PubMed]

45. Takada, K. Epstein-Barr virus and gastric carcinoma. Mol. Pathol. 2000, 53, 255-261. [CrossRef] [PubMed]

46. Burke, A.P.; Yen, T.S.; Shekitka, K.M.; Sobin, L.H. Lymphoepithelial carcinoma of the stomach with Epstein-Barr virus demonstrated by polymerase chain reaction. Mod. Pathol. 1990, 3, 377-380. [PubMed]

47. Shibata, D.; Weiss, L.M. Epstein-Barr virus-associated gastric adenocarcinoma. Am. J. Pathol. 1992, 140, 769-774. [PubMed]

48. Zhang, W. TCGA divides gastric cancer into four molecular subtypes: Implications for individualized therapeutics. Chin. J. Cancer 2014, 33, 469-470. [CrossRef]

49. The Cancer Genome Atlas Research Network. Comprehensive molecular characterization of gastric adenocarcinoma. Nature 2014, 513, 202-209. [CrossRef]

50. Chang, Y.; Cesarman, E.; Pessin, M.S.; Lee, F.; Culpepper, J.; Knowles, D.M.; Moore, P.S. Identification of herpesvirus-like DNA sequences in AIDS-associated Kaposi's sarcoma. Science 1994, 266, 1865-1869. [CrossRef]

51. Cesarman, E.; Chang, Y.; Moore, P.S.; Said, J.W.; Knowles, D.M. Kaposi's sarcoma-associated herpesvirus-like DNA sequences in AIDS-related body-cavity-based lymphomas. N. Engl. J. Med. 1995, 332, 1186-1191. [CrossRef] [PubMed]

52. Soulier, J.; Grollet, L.; Oksenhendler, E.; Cacoub, P.; Cazals-Hatem, D.; Babinet, P.; D'Agay, M.F.; Clauvel, J.P.; Raphael, M.; Degos, L. Kaposi's sarcoma-associated herpesvirus-like DNA sequences in multicentric Castleman's disease. Blood 1995, 86, 1276-1280. [CrossRef]

53. McHugh, D.; Caduff, N.; Barros, M.H.M.; Rämer, P.C.; Raykova, A.; Murer, A.; Landwing, V.; Quast, I.; Styles, C.T.; Spohn, M.; et al. Persistent KSHV infection increases EBV-associated tumor formation in vivo via enhanced EBV lytic gene expression. Cell Host Microbe 2017, 22, 61-73. [CrossRef] [PubMed]

54. Flore, O.; Rafii, S.; Ely, S.; O'Leary, J.J.; Hyjek, E.M.; Caserman, E. Transformation of primary human endothelial cells by Kaposi's sarcoma-associated herpesvirus. Nature 1998, 394, 588-592. [CrossRef] [PubMed]

55. Lee, H.; Veazey, R.; Williams, K.; Li, M.; Guo, J.; Neipel, F.; Fleckenstein, B.; Lackner, A.; Desrosiers, R.C.; Jung, J.U. Deregulation of cell growth by the K1 gene of Kaposi's sarcoma-associated herpesvirus. Nat. Med. 1998, 4, 435-440. [CrossRef] [PubMed] 
56. Tomlinson, C.C.; Damania, B. The K1 protein of Kaposi's sarcoma-associated herpesvirus activates the Akt signaling pathway. J. Virol. 2004, 78, 1918-1927. [CrossRef] [PubMed]

57. Lee,H.; Guo, J.; Li, M.; Choi, J.K.; DeMaria, M.; Rosenzweig, M.; Jung, J.U. Identification of an immunoreceptor tyrosine-based activation motif of K1 transforming protein of Kaposi's sarcoma-associated herpesvirus. Mol. Cell. Biol. 1998, 18, 5219-5228. [CrossRef] [PubMed]

58. Wang, L.; Wakisaka, N.; Tomlinson, C.C.; DeWire, S.M.; Krall, S.; Pagano, J.S.; Damania, B. The Kaposi's sarcoma-associated herpesvirus (KSHV/HHV-8) K1 protein induces expression of angiogenic and invasion factors. Cancer Res. 2004, 64, 2774-2781. [CrossRef]

59. Wang, L.; Dittmer, D.P.; Tomlinson, C.C.; Fakhari, F.D.; Damania, B. Immortalization of primary endothelial cells by the K1 protein of Kaposi's sarcoma-associated herpesvirus. Cancer Res. 2006, 66, 3658-3666. [CrossRef]

60. Bais, C.; Van Geelen, A.; Eroles, P.; Mutlu, A.; Chiozzini, C.; Dias, S.; Silverstein, R.L.; Rafii, S.; Mesri, E.A. Kaposi's sarcoma associated herpesvirus $G$ protein-coupled receptor immortalizes human endothelial cells by activation of the VEGF receptor-2/ KDR. Cancer Cell 2003, 3, 131-143. [CrossRef]

61. Yang, T.Y.; Chen, S.C.; Leach, M.W.; Manfra, D.; Homey, B.; Wiekowski, M.; Sullivan, L.; Jenh, C.H.; Narula, S.K.; Chensue, S.W.; et al. Transgenic expression of the chemokine receptor encoded by human herpesvirus 8 induces an angioproliferative disease resembling Kaposi's sarcoma. J. Exp. Med. 2000, 191, 445-454. [CrossRef] [PubMed]

62. Watanabe, T.; Sugaya, M.; Atkins, A.M.; Aquilino, E.A.; Yang, A.; Borris, D.L.; Brady, J.; Blauvelt, A. Kaposi's sarcoma-associated herpesvirus latency-associated nuclear antigen prolongs the life span of primary human umbilical vein endothelial cells. J. Virol. 2003, 77, 6188-6196. [CrossRef]

63. Fakhari, F.D.; Jeong, J.H.; Kanan, Y.; Dittmer, D.P. The latency-associated nuclear antigen of Kaposi sarcoma-associated herpesvirus induces B cell hyperplasia and lymphoma. J. Clin. Investig. 2006, 116, 735-742. [CrossRef] [PubMed]

64. He, M.; Cheng, F.; da Silva, S.R.; Tan, B.; Sorel, O.; Gruffaz, M.; Li, T.; Gao, S.J. Molecular Biology of KSHV in Relation to HIV/AIDS-Associated Oncogenesis. Cancer Treat. Res. 2019, 177, 23-62. [CrossRef] [PubMed]

65. Münz, C. The role of dendritic cells in immune control and vaccination against $\gamma$-herpesviruses. Viruses 2019, 11, 1125. [CrossRef]

66. Bigi, R.; Landis, J.T.; An, H.; Caro-Vegas, C.; Raab-Traub, N.; Dittmer, D.P. Epstein-Barr virus enhances genome maintenance of Kaposi sarcoma-associated herpesvirus. Proc. Natl. Acad. Sci. USA 2018, 115, E11379-E11387. [CrossRef] [PubMed]

67. Barbera, A.J.; Chodaparambil, J.V.; Kelley-Clarke, B.; Joukov, V.; Walter, J.C.; Luger, K.; Kaye, K.M. The nucleosomal surface as a docking station for Kaposi's sarcoma herpesvirus LANA. Science 2006, 311, 856-861. [CrossRef]

68. zur Hausen, H. Papillomaviruses in the causation of human cancers-A brief historical account. Virology 2009, 384, 260-265. [CrossRef] [PubMed]

69. Serrano, B.; de Sanjosé, S.; Tous, S.; Quiros, B.; Muñoz, N.; Bosch, X.; Alemany, L. Human papillomavirus genotype attribution for HPVs 6, 11, 16, 18, 31, 33, 45, 52 and 58 in female anogenital lesions. Eur. J. Cancer 2015, 51, 1732-1741. [CrossRef] [PubMed]

70. Dunne, E.F.; Park, I.U. HPV and HPV-associated diseases. Infect. Dis. Clin. N. Am. 2013, 27, 765-778. [CrossRef]

71. zur Hausen, H.; Meinhof, W.; Scheiber, W.; Bornkamm, G.W. Attempts to detect virus-specific DNA in human tumors: 1 . Nucleic acid hybridizations with complementary RNA of human wart virus. Int. J. Cancer 1974, 13, 650-656. [CrossRef]

72. Zur Hausen, H.; Schulte-Holthausen, H.; Wolf, H.; Dörries, K.; Egger, H. Attempts to detect virus-specific DNA in human tumors: II. Nucleic acid hybridizations with complementary RNA of human herpes group viruses. Int. J. Cancer 1974, 13, 657-664. [CrossRef]

73. Zur Hausen, H. Human papillomaviruses and their possible role in squamous cell carcinomas. Curr. Top. Microbio. Immunol. 1977, 78, 1-30. [CrossRef]

74. The Nobel Prize. Available online: https://www.nobelprize.org/prizes/medicine/2008/hausen/facts/ (accessed on 3 April 2020).

75. Danos, O.; Katinka, M.; Yaniv, M. Human papillomavirus 1a complete DNA sequence: A novel type of genome organization among papovaviridae. EMBO J. 1982, 1, 231-236. [CrossRef] 
76. Ryndock, E.J.; Meyers, C. A risk for non-sexual transmission of human papillomavirus? Expert Rev. Anti Infect. Ther. 2014, 12, 1165-1170. [CrossRef] [PubMed]

77. Jones, V.; Smith, S.J.; Omar, H.A. Nonsexual transmission of anogenital warts in children: A retrospective analysis. Sci. World J. 2007, 7, 1896-1899. [CrossRef]

78. Sapp, M.; Fligge, C.; Petzak, I.; Harris, J.R.; Streeck, R.E. Papillomavirus assembly requires trimerization of the major capsid protein by disulfides between two highly conserved cysteines. J. Virol. 1998, 72, 6186-6189. [CrossRef] [PubMed]

79. Sabeena, S.; Bhat, P.; Kamath, V.; Arunkumar, G. Possible non-sexual modes of transmission of human papilloma virus. J. Obstet Gynaecol. Res. 2017, 43, 429-435. [CrossRef] [PubMed]

80. Howley, P.; Lowy, D. Papillomaviruses and their replication. In Fields Virology, 4th ed.; Knipe, D.M., Howley, P.M., Eds.; Lippincott Williams \& Wilkins: Philadelfia, PA, USA, 2001; pp. 2197-2229.

81. Campo, M.S. Animal models of papillomavirus pathogenesis. Virus Res. 2002, 89, 249-261. [CrossRef]

82. Hebner, C.M.; Laimins, L.A. Human papillomaviruses: Basic mechanisms of pathogenesis and oncogenicity. Rev. Med. Virol. 2006, 16, 83-97. [CrossRef] [PubMed]

83. Scheffner, M.; Werness, B.A.; Huibregtse, J.M.; Levine, A.J.; Howley, P.M. The E6 oncoprotein encoded by human papillomavirus types 16 and 18 promotes the degradation of p53. Cell 1990, 63, 1129-1136. [CrossRef]

84. Rolfe, M.; Beer-Romero, P.; Glass, S.; Eckstein, J.; Berdo, I.; Theodoras, A.; Pagano, M.; Draetta, G. Reconstitution of p53-ubiquitinylation reactions from purified components: The role of human ubiquitin-conjugating enzyme UBC4 and E6-associated protein (E6AP). Proc. Natl. Acad. Sci. USA 1995, 92, 3264-3268. [CrossRef]

85. Klingelhutz, A.J.; Foster, S.A.; McDougall, J.K. Telomerase activation by the E6 gene product of human papillomavirus type 16. Nature 1996, 380, 79-82. [CrossRef]

86. Dyson, N.; Howley, P.M.; Münger, K.; Harlow, E. The human papilloma virus-16 E7 oncoprotein is able to bind to the retinoblastoma gene product. Science 1989, 243, 934-937. [CrossRef]

87. Helt, A.M.; Galloway, D.A. Mechanisms by which DNA tumor virus oncoproteins target the Rb family of pocket proteins. Carcinogenesis 2003, 24, 159-169. [CrossRef] [PubMed]

88. Kash, N.; Lee, M.A.; Kollipara, R.; Downing, C.; Guidry, J.; Tyring, S.K. Safety and Efficacy Data on Vaccines and Immunization to Human Papillomavirus. J. Clin. Med. 2015, 4, 614-633. [CrossRef] [PubMed]

89. Shepard, C.W.; Simard, E.P.; Finelli, L.; Fiore, A.F.; Bell, B.P. Hepatitis B Virus Infection: Epidemiology and Vaccination. Epidemiol. Rev. 2006, 28, 112-125. [CrossRef] [PubMed]

90. Kew, M.C. Epidemiology of chronic hepatitis b virus infection, hepatocellular carcinoma, and hepatitis $b$ virus-induced hepatocellular carcinoma. Pathol. Biol. 2010, 58, 273-277. [CrossRef]

91. Ahmadi Vasmehjani, A.; Javeshghani, D.; Baharlou, R.; Shayestehpour, M.; Mousavinasab, S.D.; Joharinia, N.; Enderami, S.E. Hepatitis A infection in patients with chronic viral liver disease: A cross-sectional study in Jahrom, Iran. Epidemiol. Infect. 2015, 134, 534-539. [CrossRef]

92. Baghbanian, M.; Mousa, S.A.H.; Doosti, M.; Moghimi, M. Association between gastric pathology and hepatitis B virus infection in patients with or without helicobacter pylori. Asian Pac. J. Cancer Prev. 2019, 20, 2177-2180. [CrossRef]

93. Bouchard, M.J.; Schneider, R.J. The Enigmatic X Gene of Hepatitis B Virus. J. Virol. 2004, 78, 12725-12734. [CrossRef]

94. Wentz, M.J.; Becker, S.A.; Slagle, B.L. Dissociation of DDB1-binding and transactivation properties of the hepatitis B virus X protein. Virus Res. 2000, 68, 87-92. [CrossRef]

95. Chang, S.-F.; Netter, H.J.; Hildt, E.; Schuster, R.; Schaefer, S.; Hsu, Y.-C.; Rang, A.; Will, H. Duck Hepatitis B Virus Expresses a Regulatory HBx-Like Protein from a Hidden Open Reading Frame. J. Virol. 2001, 75, 161-170. [CrossRef]

96. Lupberger, J.; Hildt, E. Hepatitis B virus-induced oncogenesis. World J. Gastroenterol. 2007, 13, 74-81. [CrossRef]

97. Martin-Vilchez, S.; Lara-Pezzi, E.; Trapero-Marugán, M.; Moreno-Otero, R.; Sanz-Cameno, P. The molecular and pathophysiological implications of hepatitis B X antigen in chronic hepatitis B virus infection. Rev. Med. Virol. 2011, 21, 315-329. [CrossRef] [PubMed]

98. Zemel, R.; Issachar, A.; Tur-Kaspa, R. The Role of Oncogenic Viruses in the Pathogenesis of Hepatocellular Carcinoma. Clin. Liver Dis. 2011, 15, 261-279. [CrossRef] [PubMed] 
99. Tian, Y.; Yang, W.; Song, J.; Wu, Y.; Ni, B. Hepatitis B Virus X Protein-Induced Aberrant Epigenetic Modifications Contributing to Human Hepatocellular Carcinoma Pathogenesis. Mol. Cell. Biol. 2013, 33, 2810-2816. [CrossRef]

100. Mesri, E.A.; Feitelson, M.A.; Munger, K. Human viral oncogenesis: A cancer hallmarks analysis. Cell Host Microbe 2014, 15, 266-282. [CrossRef] [PubMed]

101. Yip, W.K.; Cheng, A.S.L.; Zhu, R.; Lung, R.W.M.; Tsang, D.P.F.; Lau, S.S.K.; Chen, Y.; Sung, J.G.; Lai, P.B.S.; $\mathrm{Ng}$, E.K.O.; et al. Carboxyl-terminal truncated HBx regulates a distinct microRNA transcription program in Hepatocellular carcinoma development. PLoS ONE 2011, 6, e22888. [CrossRef]

102. Becker, S.A.; Lee, T.-H.; Butel, J.S.; Slagle, B.L. Hepatitis B Virus X Protein Interferes with Cellular DNA Repair. J. Virol. 1998, 72, 266-272. [CrossRef] [PubMed]

103. An, J.; Kim, J.W.; Shim, J.H.; Han, S.; Yu, C.S.; Choe, J.; Lee, D.; Kim, K.M.; Lim, Y.-S.; Chung, Y.-H.; et al. Chronic hepatitis B infection and non-hepatocellular cancers: A hospital registry-based, case-control study. PLoS ONE 2018, 13, e0193232. [CrossRef]

104. Ghasemi, M.; Vahedi Larijani, L.; Abediankenari, S. Investigation of Relationship between Hepatitis B Virus and Gastric Adenocarcinoma. Iran Red Crescent Med. J. 2012, 14, 453-454.

105. Wei, X.L.; Qiu, M.Z.; Jin, Y.; Huang, Y.X.; Wang, R.Y.; Chen, W.W.; Wang, D.S.; Wang, F.; Luo, H.Y.; Zhang, D.S.; et al. Hepatitis B virus infection is associated with gastric cancer in China: An endemic area of both diseases. Br. J. Cancer 2015, 112, 1283-1290. [CrossRef]

106. Chen, N.L.; Bai, L.; Deng, T.; Zhang, C.; Kong, Q.Y.; Chen, H. Expression of hepatitis B virus antigen and Helicobacter pylori infection in gastric mucosa of patients with chronic liver disease. Hepatobiliary Pancreat Dis. Int. 2004, 3, 223-225.

107. Lu, T.; Yang, Q.; Li, M.; Zhang, J.; Zou, J.; Huang, L.; Lin, J.; Jin, H.; He, J. HBV infection and extra-hepatic cancers in adolescents and 20s: A retrospective study in China. Cancer Epidemiol. 2018, 55, 149-155. [CrossRef] [PubMed]

108. Niepmann, M.; Gerresheim, G.K. Hepatitis C Virus Translation Regulation. Int. J. Mol. Sci. 2020, $21,2328$. [CrossRef] [PubMed]

109. Romero-López, C.; Berzal-Herranz, A. The Role of the RNA-RNA Interactome in the Hepatitis C Virus Life Cycle. Int. J. Mol. Sci. 2020, 21, 1479. [CrossRef] [PubMed]

110. Koike, K. The Oncogenic Role of Hepatitis C Virus. Recent Results Cancer Res. 2014, 193, 97-111. [CrossRef] [PubMed]

111. WHO World Health Organization (WHO). Fact Sheets-Hepatitis C. Available online: http://www.who.int/ en/news-room/fact-sheets/detail/hepatitis-c (accessed on 3 April 2020).

112. Brechot, C. Pathogenesis of hepatitis B virus-related hepatocellular carcinoma: Old and new paradigms. Gastroenterology 2004, 127, 56-61. [CrossRef] [PubMed]

113. Banerjee, A.; Ray, R.B.; Ray, R. Oncogenic potential of hepatitis C virus proteins. Viruses 2010, 2, $2108-2133$. [CrossRef] [PubMed]

114. Jeong, S.W.; Jang, J.Y.; Chung, R.T. Hepatitis C virus and hepatocarcinogenesis. Clin. Mol. Hepatol. 2012, 18, 347-356. [CrossRef]

115. Vescovo, T.; Refolo, G.; Vitagliano, G.; Fimia, G.M.; Piacentini, M. Molecular mechanisms of hepatitis C virus-induced hepatocellular carcinoma. Clin. Microbiol. Infect. 2016, 22, 853-861. [CrossRef]

116. Jindal, A.; Thadi, A.; Shailubhai, K. Hepatocellular Carcinoma: Etiology and Current and Future Drugs. J. Clin. Exp. Hepatol. 2019, 9, 221-232. [CrossRef]

117. Evans, A.S. The spectrum of infections with Epstein-Barr virus: A hypothesis. J. Infect. Dis. 1971, 124, 330-337. [CrossRef]

118. Iizasa, H.; Nanbo, A.; Nishikawa, J.; Jinushi, M.; Yoshiyama, H. Epstein-Barr Virus (EBV)-associated gastric carcinoma. Viruses 2012, 4, 3420-3439. [CrossRef] [PubMed]

119. Futsch, N.; Mahieux, R.; Dutartre, H. HTLV-1, the other pathogenic yet neglected human retrovirus: From transmission to therapeutic treatment. Viruses 2018, 10, 1. [CrossRef] [PubMed]

120. Igakura, T.; Stinchcombe, J.C.; Goon, P.K.C.; Taylor, G.P.; Weber, J.N.; Griffiths, G.M.; Tanaka, Y.; Osame, M.; Bangham, C.R. Spread of HTLV-I between lymphocytes by virus-induced polarization of the cytoskeleton. Science 2003, 299, 1713-1716. [CrossRef] 
121. Majorovits, E.; Nejmeddine, M.; Tanaka, Y.; Taylor, G.P.; Fuller, S.D.; Bangham, C.R.M. Human T-Lymphotropic Virus-1 visualized at the virological synapse by electron tomography. PLoS ONE 2008, 3, e2251. [CrossRef] [PubMed]

122. Omsland, M.; Pise-Masison, C.; Fujikawa, D.; Galli, V.; Fenizia, C.; Parks, R.W.; Gjertsen, B.T.; Franchini, G.; Andersen, V. Inhibition of Tunneling Nanotube (TNT) formation and human T-cell Leukemia Virus Type 1 (HTLV-1) transmission by cytarabine. Sci. Rep. 2018, 8, 11118. [CrossRef] [PubMed]

123. Pinto, D.O.; DeMarino, C.; Pleet, M.L.; Cowen, M.; Branscome, H.; Al Sharif, S.; Jones, J.; Dutartre, H.; Lepene, B.; Liotta, L.A.; et al. HTLV-1 extracellular vesicles promote cell-to-cell contact. Front. Microbiol. 2019, 10, 2147. [CrossRef] [PubMed]

124. Tagaya, Y.; Gallo, R.C. The exceptional oncogenicity of HTLV-1. Front. Microbiol. 2017, 8, 1425. [CrossRef] [PubMed]

125. Zhao, T. The role of HBZ in HTLV-1-induced oncogenesis. Viruses 2016, 8, 34. [CrossRef] [PubMed]

126. Cook, L.; Melamed, A.; Yaguchi, H.; Bangham, C.R. The impact of HTLV-1 on the cellular genome. Curr. Opin. Virol. 2017, 26, 125-131. [CrossRef] [PubMed]

127. Hirata, T.; Nakamoto, M.; Kinjo, N.; Hokama, A.; Kinjo, F.; Fujita, J. Low prevalence of human T cel lymphotropic virus type 1 infection in patients with gastric Cancer. J. Gastroenterol. Hepatol. 2007, 22, 2238-2241. [CrossRef]

128. Matsumoto, S.; Yamasaki, K.; Tsuji, K.; Shirahama, S. Human T lymphotropic virus type 1 infection and gastric cancer development in Japan. J. Infect. Dis. 2008, 198, 10-15. [CrossRef] [PubMed]

129. Tahaei, S.M.; Mohebbi, S.R.; Fatemi, S.R.; Mohammadi, P.; Malek, F.N.; Azimzadeh, P.; Almasi, S.; Mirsattari, D.; Zali, M.R. Low frequency of human T-cell lymphotropic virus 1 antibodies in Iranian gastric cancer patients in comparison to controls. Asian Pac. J. Cancer Prev. 2011, 12, 2447-2450. [PubMed]

130. Levy, J.A. Pathogenesis of human immunodeficiency virus infection. Microbiol. Rev. 1993, 57, $183-289$. [CrossRef] [PubMed]

131. World Health Organization-HIV/AIDS. Available online: https:/www.who.int/news-room/fact-sheets/ detail/hiv-aids (accessed on 5 May 2020).

132. National Cancer Institute-HIV Infection and Cancer Risk. Available online: https://www.cancer.gov/aboutcancer/causes-prevention/risk/infectious-agents/hiv-fact-sheet (accessed on 5 May 2020).

133. Goncalves, P.H.; Montezuma-Rusca, J.M.; Yarchoan, R.; Uldrick, T.S. Cancer prevention in HIV-infected populations. Semin. Oncol. 2016, 43, 173-188. [CrossRef]

134. Cutrell, J.; Bedimo, R. Non-AIDS-defining cancers among HIV-infected patients. Curr. HIV/AIDS Rep. 2013, 10, 207-216. [CrossRef]

135. de Falco, G.; Bellan, C.; Lazzi, S.; Claudio, P.P.; la Sala, D.; Cinti, C.; Tosi, P.; Giordano, A.; Leoncini, L. Interaction between HIV-1 Tat and pRb2/p130: A possible mechanism in the pathogenesis of AIDS-related neoplasms. Oncogene 2003, 22, 6214-6219. [CrossRef]

136. Wu, R.F.; Gu, Y.; Xu, Y.C.; Mitola, S.; Bussolino, F.; Terada, L.S. Human Immunodeficiency Virus Type 1 Tat Regulates Endothelial Cell Actin Cytoskeletal Dynamics through PAK1 Activation and Oxidant Production. J. Virol. 2004, 78, 779-789. [CrossRef]

137. Grulich, A.E.; van Leeuwen, M.T.; Falster, M.O.; Vajdic, C.M. Incidence of cancers in people with HIV/AIDS compared with immunosuppressed transplant recipients: A meta-analysis. Lancet 2007, 370,59-67. [CrossRef]

138. Hernández-Ramírez, R.U.; Shiels, M.S.; Dubrow, R.; Engels, E.A. Cancer risk in HIV-infected people in the USA from 1996 to 2012: A population-based, registry-linkage study. Lancet HIV 2017, 4, e495-e504. [CrossRef]

139. Wang, C.C.J.; Silverberg, M.J.; Abrams, D.I. Non-AIDS-defining malignancies in the HIV-infected population. Curr. Infect. Dis. Rep. 2014, 16, 406. [CrossRef]

140. Silverberg, M.J.; Lau, B.; Achenbach, C.J.; Jing, Y.; Althoff, K.N.; D’Souza, G.; Engels, E.A.; Hessol, N.A.; Brooks, J.T.; Burchell, A.N.; et al. Cumulative incidence of cancer among persons with HIV in North America: A cohort study. Ann. Intern. Med. 2015, 163, 507-518. [CrossRef]

141. Persson, E.C.; Shiels, M.S.; Dawsey, S.M.; Bhatia, K.; Anderson, L.A.; Engels, E.A. Increased risk of stomach and esophageal malignancies in people with AIDS. Gastroenterology 2012, 143, 943-950.e2. [CrossRef]

142. Persson, E.C.; Shiels, M.S.; Dawsey, S.M.; Bhatia, K.; Anderson, L.A.; Engels, E.A. Erratum: Increased Risk of Stomach and Esophageal Malignancies in People with AIDS. Gastroenterology 2016, 150, 1048. [CrossRef] [PubMed] 
143. Kangasniemi, L.; Kiviluoto, T.; Kanerva, A.; Raki, M.; Sarkioja, M.; Wu, H.; Marini, F.; Höckerstedt, K.; Isoniemi, H.; Alfthan, H.; et al. Infectivity-enhanced adenoviruses deliver efficacy in clinical samples and ortotopic models of disseminated gastric cancer. Clin. Cancer Res. 2006, 12, 3137-3144. [CrossRef] [PubMed]

144. Zhu, Y.; Tao, M.; Wu, J.; Meng, Y.; Xu, C.; Tian, T.; Zhou, X.; Xiang, J.; Zhang, H.; Xie, Y. Adenovirus-directed expression of TIPE2 suppresses gastric cancer growth via induction of apoptosis and inhibition of AKT and ERK1/2 signaling. Cancer Gene Ther. 2016, 23, 98-106. [CrossRef]

145. Rosewell Shaw, A.; Suzuki, M. Recent advances in oncolytic adenovirus therapies for cancer. Curr. Opin. Virol. 2016, 21, 9-15. [CrossRef] [PubMed]

146. Zhou, W.; Dai, S.; Zhu, H.; Song, Z.; Cai, Y.; Lee, J.B.; Hu, X.; Fang, B.; He, C.; Huang, X. Telomerase-specific oncolytic adenovirus expressing TRAIL suppresses peritoneal dissemination of gastric cancer. Gene Ther. 2017, 24, 199-207. [CrossRef] [PubMed]

147. Pang, T.; Wang, X.; Gao, J.; Chen, W.; Shen, X.J.; Nie, M.M.; Luo, T.; Yin, K.; Fang, G.; Wang, K.X.; et al. Fiber-modified hexon-chimeric oncolytic adenovirus targeting cancer associated fibroblasts inhibits tumor growth in gastric carcinoma. Oncotarget 2017, 8, 76468-76478. [CrossRef]

148. Wang, M.; Hong, Y.; Feng, Q.; Pan, X.; Cui, J.; Lei, J.; Fang, H.; Yang, J. Recombinant adenovirus KGHV500 and CIK cells codeliver anti-p21-Ras scFv for treatment of gastric cancer with wild-type Ras overexpression. Mol. Ther. Oncolytics 2018, 11, 90-101. [CrossRef]

149. Ono, H.A.; Davydova, J.G.; Adachi, Y.; Takayama, K.; Barker, S.D.; Reynolds, P.N.; Krasnykh, V.N.; Kunisaki, C.; Shimada, H.; Curiel, D.T.; et al. Promoter-controlled infectivity-enhanced conditionally replicate adenoviral vectors for the treatment of gastric cancer. J. Gastroenterol. 2005, 40, 31-42. [CrossRef]

150. Yokoda, R.; Nagalo, B.M.; Arora, M.; Egan, J.B.; Bogenberger, J.M.; DeLeon, T.T.; Zhou, Y.; Ahn, Y.; Borad, M.J. Oncolytic virotherapy in upper gastrointestinal tract cancers. Oncolytic Virother. 2018, 7, 13-24. [CrossRef]

151. Yin, H.; Huang, X.; Tao, M.; Hu, Q.; Qiu, J.; Chen, W.; Wu, J.; Xie, Y. Adenovirus-mediated TIPE2 overexpression inhibits gastric cancer metastasis via reversal of epithelial-mesenchymal transition. Cancer Gene Ther. 2017, 24, 180-188. [CrossRef] [PubMed]

152. Zhao, Q.; Zhao, M.; Dong, T.; Zhou, C.; Peng, Y.; Zhou, X.; Fan, B.; Ma, W.; Han, M.; Liu, S. Tumor necrosis factor-alpha-induced protein-8 like-2 (TIPE2) upregulates p27 to decrease gastric cancer cell proliferation. J. Cell Biochem. 2015, 116, 1121-1129. [CrossRef]

153. Davis, J.J.; Wang, L.; Dong, F.; Zhang, L.; Guo, W.; Teraishi, F.; Xu, K.; Ji, L.; Fang, B. Oncolysis and suppression of tumor growth by a GFP-expressing oncolytic adenovirus controlled by an hTERT and CMV hybrid promoter. Cancer Gene Ther. 2006, 13, 720-723. [CrossRef] [PubMed]

154. Kaufman, H.L.; Kohlhapp, F.J.; Zloza, A. Oncolytic viruses: A new class of immunotherapy drugs. Nat. Rev. Drug. Discov. 2015, 14, 642-662. [CrossRef] [PubMed]

155. Bommareddy, P.K.; Shettigar, M.; Kaufman, H.L. Integrating oncolytic viruses in combination cancer immunotherapy. Nat. Rev. Immunol. 2018, 18, 498-513. [CrossRef] [PubMed]

156. Moore, A.E. The Destructive Effect of the Virus of Russian Far East Encephalitis on the Transplantable Mouse Sarcoma 180. Cancer 1949, 2, 525-534. [CrossRef]

157. Moore, A.E. Effect of Inoculation of the Viruses of Influenza A and Herpes Simplex on the Growth of Transplantable Tumors in Mice. Cancer 1949, 2, 516-524. [CrossRef]

158. Trager, M.H.; Geskin, L.J.; Saenger, Y.M. Oncolytic Viruses for the Treatment of Metastatic Melanoma. Curr. Treat. Options Oncol. 2020, 21, 26. [CrossRef]

159. Garber, K. China Approves World's First Oncolytic Virus Therapy for Cancer Treatment. J. Natl. Cancer Inst. 2006, 98, 298-300. [CrossRef]

160. Chiocca, E.A.; Rabkin, S.D. Oncolytic viruses and their application to cancer immunotherapy. Cancer Immunol. Res. 2014, 2, 295-300. [CrossRef] [PubMed]

161. Russell, L.; Peng, K.-W. The emerging role of oncolytic virus therapy against cancer. Chin. Clin. Oncol. 2018, 7, 5. [CrossRef] [PubMed]

162. Ramesh, K.V.R.N.S.; Shankar, K.R. Oncolytic Viruses for the Treatment of Cancer (A Review). Biomed. Pharmacol. J. 2009, 2, 213-226.

163. Chen, S.-H.; Pan, P.-Y.; Eisenstein, S. Immune cells: More than simple carriers for systemic delivery of oncolytic viruses. Oncolytic Virother. 2014, 3, 83. [CrossRef]

164. Oncolytic Virus Therapy—Cancer Research Institute (CRI). Available online: https://www.cancerresearch. org/immunotherapy/treatment-types/oncolytic-virus-therapy (accessed on 20 May 2020). 
165. Burke, M.J. Oncolytic Seneca Valley Virus: Past perspectives and future directions. Oncolytic Virother. 2016, 5, 81-89. [CrossRef] [PubMed]

166. Israelsson, S.; Jonsson, N.; Gullberg, M.; Lindberg, A.M. Cytolytic replication of echoviruses in colon cancer cell lines. Virol. J. 2011, 8, 473. [CrossRef] [PubMed]

167. McCarthy, C.; Jayawardena, N.; Burga, L.N.; Bostina, M. Developing picornaviruses for cancer therapy. Cancers 2019, 11, 685. [CrossRef]

168. Mohamadi, A.; Pagès, G.; Hashemzadeh, M.S. The important roles of oncolytic viruses in common cancers treatments. Curr. Cancer Ther. Rev. 2020, 16. [CrossRef]

169. US10624935B2-Preparat Parwowirusa do Leczenia Nowotworów-Patenty Google. Available online: https://patents.google.com/patent/US10624935B2/en?oq=US10624935 (accessed on 20 May 2020).

170. Gong, J.; Sachdev, E.; Mita, A.C.; Mita, M.M. Clinical development of reovirus for cancer therapy: An oncolytic virus with immune-mediated antitumor activity. World J. Methodol. 2016, 6, 25. [CrossRef]

171. Rahman, M.M.; McFadden, G. Oncolytic Virotherapy with Myxoma Virus. J. Clin. Med. 2020, 9, 171. [CrossRef]

172. Russell, S.J. RNA viruses as virotherapy agents. Cancer Gene Ther. 2002, 9, 961-966. [CrossRef] [PubMed]

173. US10577591B2-Mumps Virus as a Potential Oncolytic Agent-Google Patents. Available online: https: //patents.google.com/patent/US10577591B2/en (accessed on 20 May 2020).

174. Watanabe, D.; Goshima, F. Oncolytic virotherapy by HSV. Adv. Exp. Med. Biol. 2018, 1045, 63-84. [CrossRef] [PubMed]

175. Todo, T.; Martuza, R.L.; Rabkin, S.D.; Johnson, P.A. Oncolytic herpes simplex virus vector with enhanced MHC class I presentation and tumor cell killing. Proc. Natl. Acad. Sci. USA 2001, 98, 6396-6401. [CrossRef] [PubMed]

176. Tsuji, T.; Nakamori, M.; Nakamura, M.; Ojima, T.; Iida, T.; Katsuda, M.; Hayata, K.; Ino, Y.; Todo, T.; Yamaue, H. An armed oncolytic herpes simpex virus expressing thrombospondin-1 has an enhanced in vivo antitumor effect against human gastric cancer. Int. J. Cancer 2013, 132, 485-494. [CrossRef] [PubMed]

177. Zhang, J.H.; Wan, M.X.; Yuan, J.Y.; Pan, B.R. Do there exist synergistic antitumor effects by coexpression of herpes simplex virus thymidine kinase with cytokine genes on human gastric cancer cell line SGC7901? World J. Gastroenterol. 2004, 10, 147-151. [CrossRef]

178. Saeki, N.; Komatsuzaki, R.; Chiwaki, F.; Yanagihara, K.; Sasaki, H.A. GSDMB enhancer-driven HSV thymidine kinase-expressing vector for controlling occult peritoneal dissemination of gastric cancer cells. BMC Cancer 2015, 15, 439. [CrossRef]

179. Bennett, J.J.; Delman, K.A.; Burt, B.M.; Mariotti, A.; Malhotra, S.; Zager, J.; Petrowsky, H.; Mastorides, S.; Federoff, H.; Fong, Y. Comparison of safety, delivery, and efficacy of two oncolytic herpes viruses (G207 and NV1020) for peritoneal cancer. Cancer Gene Ther. 2002, 9, 935-945. [CrossRef]

180. Bennett, J.J.; Adusumilli, P.; Petrowsky, H.; Burt, B.M.; Roberts, G.; Delman, K.A.; Zager, J.S.; Chou, T.C.; Fong, Y. Up-regulation of GADD34 mediates the synergistic anticancer activity of mitomycin $\mathrm{C}$ and a gamma134.5 deleted oncolytic herpes virus (G207). FASEB J. 2004, 18, 1001-1003. [CrossRef]

181. Sugawara, K.; Iwai, M.; Yajima, S.; Tanaka, M.; Yanagihara, K.; Seto, Y.; Todo, T. Efficacy of a third-generation oncolytic herpes virus G47 $\triangle$ in advanced stage models of human gastric cancer. Mol. Ther. Oncolytics 2020, 17, 205-215. [CrossRef]

182. Zeng, D.; Zhang, T.; Zhou, S.; Hu, H.; Li, J.; Huang, K.; Lei, Y.; Wang, K.; Zhao, Y.; Liu, R.; et al. Proteomic analysis of gastric cancer cells treated with vesicular stomatitis virus matrix protein. Protein J. 2011, 30, 308-317. [CrossRef]

183. Jun, K.H.; Gholami, S.; Song, T.J.; Au, J.; Haddad, D.; Carson, J.; Chen, C.H.; Mojica, K.; Zanzonico, P.; Chen, N.G.; et al. A novel oncolytic viral therapy and imaging technique for gastric cancer using a genetically engineered vaccinia virus carrying the human sodium iodide symporter. J. Exp. Clin. Cancer Res. 2014, 33, 2. [CrossRef] [PubMed]

(C) 2020 by the authors. Licensee MDPI, Basel, Switzerland. This article is an open access article distributed under the terms and conditions of the Creative Commons Attribution (CC BY) license (http://creativecommons.org/licenses/by/4.0/). 